\title{
Esterification of Glycerol with Acetic Acid over Highly Active and Stable Alumina-based Catalysts: A Reaction Kinetics Study
}

\author{
S. A. Rane, S. M. Pudi, and P. Biswas* \\ Department of Chemical Engineering, Indian Institute \\ of Technology Roorkee, Roorkee- 247667, Uttarakhand, India
}

doi: 10.15255/CABEQ.2014.2093

Original scientific paper

Received: August 16, 2014

Accepted: March 3, 2016

The catalytic activity of $\mathrm{Cu}$ - or $\mathrm{Ni}$ monometallic and $\mathrm{Cu}-\mathrm{Ni}$ bimetallic $(\mathrm{Cu} / \mathrm{Ni}$ ratio $=3,1,0.33$ ) catalysts supported on $\gamma-\mathrm{Al}_{2} \mathrm{O}_{3}$ and $\mathrm{SO}_{4}^{2-} / \gamma-\mathrm{Al}_{2} \mathrm{O}_{3}$ catalysts were evaluated for esterification of glycerol. The reactions were performed in a batch reactor under reflux at standard reaction conditions: temperature $110^{\circ} \mathrm{C}$, atmospheric pressure, glycerol to acetic acid molar ratio $1: 9$, and catalyst loading $0.25 \mathrm{~g}$. The best catalytic activity was observed over $2 \mathrm{M} \mathrm{SO}_{4}^{2-} / \gamma-\mathrm{Al}_{2} \mathrm{O}_{3}$ catalyst, which showed the glycerol conversion of $97 \%$ within 2 hours of reaction. At this condition, the selectivity to glyceryl monoacetate (MAG), glyceryl diacetate (DAG), and glyceryl triacetate (TAG) were $27.0 \%$, $49.9 \%$ and $23.1 \%$, respectively, after $5 \mathrm{~h}$ of reaction. After three consecutive runs, the $2 \mathrm{M} \mathrm{SO}_{4}^{2-} / \gamma-\mathrm{Al}_{2} \mathrm{O}_{3}$ catalysts showed superior performance and no loss in activity was observed. The reaction kinetics results over $2 \mathrm{M} \mathrm{SO}_{4}^{2-} / \gamma-\mathrm{Al}_{2} \mathrm{O}_{3}$ catalyst showed that the dependence on the reaction rate to glycerol concentration was of pseudo-second order, while the activation energy was found to be $106 \mathrm{~kJ} \mathrm{~mol}^{-1}$.

Key words:

glycerol esterification, $\mathrm{Cu}-\mathrm{Ni}$ bimetallic catalysts, $\mathrm{SO}_{4}{ }^{2-} / \gamma-\mathrm{Al}_{2} \mathrm{O}_{3}$ catalyst, stability, DAG and TAG selectivity

\section{Introduction}

Recently, biomass-derived energy has been receiving more and more attention due to the depletion of conventional fossil sources at a faster rate, as well as major environmental issues. ${ }^{1}$ Biodiesel obtained by transesterification of vegetable oils and animal fats provides an alternative fuel option for the future. ${ }^{2}$ Transesterification of oils and animal fats produce glycerol in large excess $(10 \mathrm{~kg}$ glycer$\mathrm{ol} / 90 \mathrm{~kg}$ of biodiesel) as a byproduct. ${ }^{3}$ In recent decades, with the rapid development of the biodiesel industry, glycerol has been oversupplied in the market, resulting in a significant decrease in the price of glycerol. Therefore, it is essential to develop a new glycerol value-added process to make the overall biodiesel process cost-competitive and environmentally friendly.,

Various glycerol value-added processes such as esterification, hydrogenolysis, etherification, carboxylation, fermentation, production of hydrogen and syn-gas have been reported in the literature..$^{5-7}$ Among all the processes explored, esterification of glycerol with acetic acid can be a good choice of glycerol utilization. The primary products of glycerol esterification i.e., MAG, DAG and TAG has great industrial significance. MAG is used as an additive

"Corresponding author: e-mail: prakbfch@iitr.ernet.in;

prakashbiswas@gmail.com; tel.: (+91)-1332-28-5820; fax: (+1)-1332-27-6535 in the food industry and in the manufacture of explosives. DAG and TAG are used to manufacture inks, softening agents, and plasticizers. ${ }^{3,8,9}$ DAG and TAG are also useful fuel additives for reducing viscosity and improving anti-knocking property of gasoline. ${ }^{10,11}$ Moreover, MAG, DAG and TAG are also used in cryogenics as well as in the biodegradable polymer industry. ${ }^{12-14}$

Traditionally, mineral acids such as $\mathrm{H}_{2} \mathrm{SO}_{4}$, $\mathrm{HCl}$, or $\mathrm{H}_{3} \mathrm{PO}_{4}$ are used as homogeneous catalysts for the glycerol esterification reaction. ${ }^{15-17}$ However, such processes are accompanied by drawbacks such as catalyst separation, product purity, necessity of neutralization, and reactor corrosion. ${ }^{18}$ There are several studies reported in the literature regarding the use of different heterogeneous catalysts for the esterification of glycerol with acetic acid. ${ }^{3,9,11-13,19-22}$ Zeolites have been reported to give poor selectivity to DAG and TAG, mostly due to their small pore size. ${ }^{3}$ Several studies have reported that the acidity of the catalyst is an important factor affecting conversion and product selectivity.,11 Some studies have discussed the use of heteropolyacids immobilized on different supports like silica ${ }^{8}$, zirconia ${ }^{11}$, activated carbon ${ }^{12}$, and zeolites ${ }^{19}$. However, low selectivity to TAG has been reported, and some loss in activity on reuse due to leaching has been observed. $\mathrm{SnCl}_{2}$ was studied as a less corrosive alternative; however, the selectivity to TAG was poor. ${ }^{20}$ A two-step reaction using acetic anhydride in the 
second step was reported to give $100 \%$ selectivity to TAG, but the high cost of acetic anhydride is a hindrance. ${ }^{13}$ Catalysts over SBA-3 and SBA-15 have also shown good activity for the esterification reaction. ${ }^{21,23}$ Since functionalization with the sulphate group results in high acidity, and acidic catalysts are active for the esterification reaction. Sulphation of different supports like multi-walled carbon nanotubes, zirconia, and activated carbon has been reported..$^{9,24,25}$ Recently, Amberlyst and ion-exchange resins have shown very satisfactory performance on the glycerol acetylation carried out in excess of glycerol. . $^{3,10,13,26}$

However, the thermal stability of the catalyst, loss in active sites due to high polarity of the medium and low selectivity to DAG and TAG remain the main challenges in the design of a suitable catalyst. Further development of catalysts capable of providing higher DAG and TAG selectivity is necessary to ensure the successful development of the industrial process for esterification of glycerol. It is very important to design a highly stable, active, and selective catalyst to perform the reaction in mild conditions.

The overall objective of this work is to develop a novel and stable catalyst system for higher DAG and TAG selectivity. In this work, we synthesized sulphated alumina with different concentrations of $\mathrm{H}_{2} \mathrm{SO}_{4}$ and evaluated its effect on the physicochemical properties of the catalyst, glycerol conversion, and product selectivity. Also examined was the performance of $\mathrm{Cu}$ or Ni monometallic and bi-metallic catalysts supported on $\gamma-\mathrm{Al}_{2} \mathrm{O}_{3}$ with different $\mathrm{Cu} / \mathrm{Ni}$ weight ratios. The stability and reusability of the catalyst was investigated, and the results obtained are discussed in support of characterization results of fresh and used catalysts. This work shows that sulphated alumina is an active and stable catalyst for the acetylation of glycerol, resulting in high glycerol conversion and high selectivity to DAG and TAG. Finally, kinetics parameters were estimated for the most active sulphated alumina catalyst.

\section{Experimental details}

\section{Materials}

$\mathrm{Cu}\left(\mathrm{NO}_{3}\right)_{2} \cdot 3 \mathrm{H}_{2} \mathrm{O}(>99 \%$, Himedia Chemicals, India), $\mathrm{Ni}\left(\mathrm{NO}_{3}\right)_{2} \cdot 6 \mathrm{H}_{2} \mathrm{O}(>99 \%$, Merck Specialities, India) were used as metal precursors, and $\gamma-\mathrm{Al}_{2} \mathrm{O}_{3}$ (Merck Specialities, India) was used as catalyst support. Sulphuric acid (98\%, Thomas Baker, India), glycerol (99.9\%, Merck Specialities, India) and acetic acid (99.5\%, Rankem, India) were used as reactants. MAG (50\%, Alfa Aesar), DAG (50\%, Alfa Aesar), TAG (99\%, Alfa Aesar), and n-butanol
(99\%, Rankem, India) were procured and used to prepare the calibration plot.

\section{Catalyst synthesis}

Synthesis of Cu-Ni catalysts

20 wt $\% \mathrm{Cu} / \gamma-\mathrm{Al}_{2} \mathrm{O}_{3}, 20 \mathrm{wt} \% \mathrm{Ni} / \gamma-\mathrm{Al}_{2} \mathrm{O}_{3}$, and $20 \mathrm{wt} \% \mathrm{Cu}-\mathrm{Ni} / \gamma-\mathrm{Al}_{2} \mathrm{O}_{3}$ catalysts were prepared by the wetness impregnation method. ${ }^{22}$ Pre-calculated amount of precursors $\mathrm{Cu}\left(\mathrm{NO}_{3}\right)_{2} \cdot 3 \mathrm{H}_{2} \mathrm{O}$ and $\mathrm{Ni}$ $\left(\mathrm{NO}_{3}\right)_{2} \cdot 6 \mathrm{H}_{2} \mathrm{O}$ were dissolved in double-distilled water. To this metal precursor solution, $\gamma-\mathrm{Al}_{2} \mathrm{O}_{3}$ support was added slowly while stirring. Three different weight ratios $(\mathrm{Cu} / \mathrm{Ni}=3,1$, and 0.33$)$ were selected for the synthesis of bimetallic catalysts. The slurry was aged for $24 \mathrm{~h}$ at room temperature and then oven-dried for $12 \mathrm{~h}$ at $110{ }^{\circ} \mathrm{C}$, followed by calcination in air at $400{ }^{\circ} \mathrm{C}$ for $4 \mathrm{~h}$. The catalysts were labelled as $\mathrm{Cu} / \gamma-\mathrm{Al}_{2} \mathrm{O}_{3} \mathrm{Ni} / \gamma-\mathrm{Al}_{2} \mathrm{O}_{3}, \mathrm{Cu}-\mathrm{Ni}$ $(1: 3) / \gamma-\mathrm{Al}_{2} \mathrm{O}_{3}$, Cu-Ni $(1: 1) / \gamma-\mathrm{Al}_{2} \mathrm{O}_{3}$, and ${ }^{3} \mathrm{Cu}-\mathrm{Ni}$ (3:1)/ $\gamma-\mathrm{Al}_{2}^{2} \mathrm{O}_{3}$, respectively.

\section{Synthesis of sulphated alumina}

Sulphated alumina catalysts were prepared by following a method reported in literature..$^{25}$ Alumina was treated with sulphuric acid solution at three different concentrations $(0.2 \mathrm{M}, 2 \mathrm{M}$ and $4.8 \mathrm{M})$, and the treated alumina was aged for $5 \mathrm{~h}$ at room temperature, followed by drying at $110{ }^{\circ} \mathrm{C}$ for $24 \mathrm{~h}$, and calcination at $550{ }^{\circ} \mathrm{C}$ for $3 \mathrm{~h}$ in air. The sulphated alumina catalysts were labelled as $0.2 \mathrm{M} \mathrm{SO}_{4}{ }^{2-} / \gamma-\mathrm{Al}_{2} \mathrm{O}_{3}$, $2 \mathrm{M} \mathrm{SO}_{4}^{2-} / \gamma-\mathrm{Al}_{2} \mathrm{O}_{3}$ and $4.8 \mathrm{M} \mathrm{SO}_{4}^{2-} / \gamma-\mathrm{Al}_{2} \mathrm{O}_{3}$, respectively.

\section{Catalyst characterization}

The $\mathrm{N}_{2}$ adsorption-desorption isotherm and surface area of the catalysts were determined by nitrogen adsorption at liquid nitrogen temperature using the Micromeritics ASAP-2020 instrument. Prior to the measurement, the samples were degassed in a vacuum at $200{ }^{\circ} \mathrm{C}$ for $4 \mathrm{~h}$. Pore size distribution was calculated by the BJH (Barret-Joyner-Halenda) method using the desorption branch of isotherm.

The XRD spectra of catalysts were obtained using a Bruker AXS D8, diffractometer with a $\mathrm{Cu}-\mathrm{K} \alpha$ radiation $(\lambda=0.154 \mathrm{~nm})$ source. All the data were recorded at the two theta interval of $10-80^{\circ}$ with a steep of $0.02^{\circ} \mathrm{s}^{-1}$ at $3 \mathrm{~s}$ time constant. The Scherrer equation was used to calculate the average crystallite size of the metal particles using the XRD line broadening technique.

Temperature programmed desorption (TPD) with ammonia was carried out to determine the acidic property of the catalyst. The $\mathrm{NH}_{3}$-TPD experiments were carried out using Micromeritics 
Chemsorb 2720 apparatus equipped with a thermal conductivity detector. Prior to the TPD experiments, the catalyst samples were pre-treated at $150{ }^{\circ} \mathrm{C}$ for $2 \mathrm{~h}$ in a flow of helium. After pre-treatment, the catalyst samples were allowed to cool at room temperature. Then the samples were saturated with $27 \% \mathrm{NH}_{3} / \mathrm{He}$ gas mixture for $1 \mathrm{~h}$ at a flow rate of $30 \mathrm{~mL} \mathrm{~min}^{-1}$. To remove the excess ammonia, the samples were flushed with helium. The ammonia-TPD was performed using $20 \mathrm{cc} \mathrm{min}^{-1}$ of helium, heating the samples from $30{ }^{\circ} \mathrm{C}$ to $700{ }^{\circ} \mathrm{C}$ at a heating rate of $10{ }^{\circ} \mathrm{C} \mathrm{min}^{-1}$ while continuously monitoring the thermal conductive detector signals.

FT-IR analysis of sulphated alumina catalysts were recorded on a Thermo Nicolet (Model magna 760) spectrometer at room temperature in $\mathrm{KBr}$ pellets over a range of 500 to $4000 \mathrm{~cm}^{-1}$ under atmospheric conditions.

The leaching of metal from the support into the liquid medium during recycle experiments was tested by using inductively coupled plasma mass spectrometry (ICP-MS).

\section{Catalytic evaluation}

The esterification reactions were carried out at $110{ }^{\circ} \mathrm{C}$ and atmospheric pressure in a round bottom flask equipped with a reflux and a magnetic stirrer. Glycerol to acetic acid molar ratio of 1:9 (total volume of $30 \mathrm{~mL}$ ) and catalyst loading of $0.25 \mathrm{~g}$ was maintained for all reactions. In all the experiments, stirrer speed was kept constant at $700 \mathrm{rpm}$. Samples cooled to room temperature, were taken periodically, filtered, and analysed by gas chromatography.

\section{Product analysis}

A Newchrom GC (Model: 6800, India) equipped with AB-PONA (stationary phase, $50 \mathrm{~m} \times 0.2 \mathrm{~mm}$ ) column equipped with a flame ionization detector (FID) was used to detect product components such as MAG, DAG and TAG. Oven temperature was kept constant at $200{ }^{\circ} \mathrm{C}$. The FID and injector temperatures were fixed at $280{ }^{\circ} \mathrm{C}$ and $260{ }^{\circ} \mathrm{C}$, respectively. For calculating product selectivity, n-butanol was used as the internal standard. The glycerol conversion and product selectivity were defined as proposed by Zhou et al. ${ }^{27}$

Conversion of glycerol or acetic acid $(\%)=$ $[1$ - (moles of glycerol or acetic acid remaining) / initial moles of glycerol or acetic acid)] 100

Selectivity of MAG, DAG and TAG $(\%)=$ [(moles of MAG, DAG or TAG formed) / (total moles of MAG + DAG + TAG) $] \cdot 100$

\section{Results and discussion}

\section{Catalyst characterization}

The surface area, total pore volume, and the average pore diameter of catalysts are given in Table 1 . The surface area of $\gamma-\mathrm{Al}_{2} \mathrm{O}_{3}$ was $107 \mathrm{~m}^{2} \mathrm{~g}^{-1}$, and decreased $\sim 35 \%$ after metal impregnation and was in the range of $67-77 \mathrm{~m}^{2} \mathrm{~g}^{-1}$. The reduction in surface area of the catalysts was due to the structural collapse of precursor during calcinations. ${ }^{28}$ The surface area of $\mathrm{SO}_{4}{ }^{2-} / \gamma-\mathrm{Al}_{2} \mathrm{O}_{3}$ catalysts decreased significantly (52.1-2.4 $\left.\mathrm{m}^{2} \mathrm{~g}^{-1}\right)$ when $\mathrm{H}_{2} \mathrm{SO}_{4}$ concentration increased from $0.2 \mathrm{M}$ to $4.8 \mathrm{M}$. This result might be due to the blockage of pores by the active $\mathrm{SO}_{4}{ }^{2-}$ species. ${ }^{29}$ The pore volume of $\gamma-\mathrm{Al}_{2} \mathrm{O}_{3}$ supported $\mathrm{Cu}$ or $\mathrm{Ni}$ and $\mathrm{Cu}-\mathrm{Ni}$ catalysts were in the range of $0.12-0.20 \mathrm{~cm}^{-3} \mathrm{~g}^{-1}$, whereas, for $\mathrm{SO}_{4}^{2-} / \gamma-\mathrm{Al}_{2} \mathrm{O}_{3}$ catalysts it reduced significantly $\left(0.002-0.092 \mathrm{~cm}^{3} \mathrm{~g}^{-1}\right)$. The pore size of all catalysts were calculated by applying the $\mathrm{BJH}$ model for desorption isotherm data. The result shows that the average pore diameter of the $\mathrm{Cu}-\mathrm{Ni}$ catalysts is lower $(55-59 \AA)$ than that of the $\mathrm{SO}_{4}^{2-} / \gamma-\mathrm{Al}_{2} \mathrm{O}_{3}$ catalysts $(63-118 \AA)$. Moreover, the average pore diameter passed through minima with increasing $\mathrm{SO}_{4}^{2-}$ concentration on $\gamma-\mathrm{Al}_{2} \mathrm{O}_{3}$.

Table 1 -Structural parameter, specific surface area, and acidity of the catalysts

\begin{tabular}{|c|c|c|c|c|}
\hline Catalyst & $\underset{\left(\mathrm{m}^{2} \mathrm{~g}^{-1}\right)}{S_{\mathrm{BET}}}$ & $\begin{array}{c}V \\
\left(\mathrm{~cm}^{3^{\mathrm{p}}} \mathrm{g}^{-1}\right)\end{array}$ & $\begin{array}{c}D_{\mathrm{p}} \\
(\AA)\end{array}$ & $\begin{array}{c}\text { Acidity } \\
\left(\mathrm{mmol} \mathrm{NH}_{3} \mathrm{~g} \mathrm{cat}^{-1}\right)\end{array}$ \\
\hline$\gamma-\mathrm{Al}_{2} \mathrm{O}_{3}$ & 107 & 0.20 & 57 & 1.20 \\
\hline $\mathrm{Cu} / \gamma-\mathrm{Al}_{2} \mathrm{O}_{3}$ & 77 & 0.15 & 59 & 0.56 \\
\hline $\mathrm{Cu}-\mathrm{Ni}(3: 1) / \gamma-\mathrm{Al}_{2} \mathrm{O}_{3}$ & 67 & 0.13 & 57 & 0.70 \\
\hline $\mathrm{Cu}-\mathrm{Ni}(1: 1) / \gamma-\mathrm{Al}_{2} \mathrm{O}_{3}$ & 78 & 0.15 & 56 & 0.61 \\
\hline $\mathrm{Cu}-\mathrm{Ni}(1: 3) / \gamma-\mathrm{Al}_{2} \mathrm{O}_{3}$ & 69 & 0.12 & 55 & 0.89 \\
\hline $\mathrm{Ni} / \gamma-\mathrm{Al}_{2} \mathrm{O}_{3}$ & 71 & 0.12 & 55 & 0.41 \\
\hline 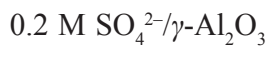 & 52.1 & 0.092 & 62.9 & 1.32 \\
\hline $2 \mathrm{M} \mathrm{SO}_{4}^{2-} / \gamma-\mathrm{Al}_{2} \mathrm{O}_{3}$ & 8.4 & 0.012 & 38.3 & 2.51 \\
\hline $4.8 \mathrm{M} \mathrm{SO}_{4}^{2-} / \gamma-\mathrm{Al}_{2} \mathrm{O}_{3}$ & 2.4 & 0.002 & 117.6 & 1.98 \\
\hline
\end{tabular}

The XRD patterns of calcined $\mathrm{Cu} / \gamma-\mathrm{Al}_{2} \mathrm{O}_{3}$, $\mathrm{Ni} / \gamma-\mathrm{Al}_{2} \mathrm{O}_{3}$ and $\mathrm{Cu}-\mathrm{Ni} / \gamma-\mathrm{Al}_{2} \mathrm{O}_{3}$ catalysts are shown in Fig. $1 \mathrm{~A}$. For the $\mathrm{Cu} / \gamma-\mathrm{Al}_{2} \mathrm{O}_{3}$ catalyst, the diffraction peaks were obtained at $2 \theta=35.5^{\circ}, 38.7^{\circ}, 48.6^{\circ}$ and $61.5^{\circ}$, corresponding to (111), (111), (202) and (113) planes of monoclinic CuO (JCPDS: 41-0254). A broad peak was observed for all the catalysts at $2 \theta=67.5^{\circ}$ corresponding to $\mathrm{Al}_{2} \mathrm{O}_{3}$ (JCPDS: $86-1410$ ). The intensity of the peaks detected for $\mathrm{Cu} / \gamma-\mathrm{Al}_{2} \mathrm{O}_{3}$ catalysts indicates that $\mathrm{CuO}$ is of good crystalline nature. The XRD pattern of the $\mathrm{Ni} / \gamma-\mathrm{Al}_{2} \mathrm{O}_{3}$ catalyst 

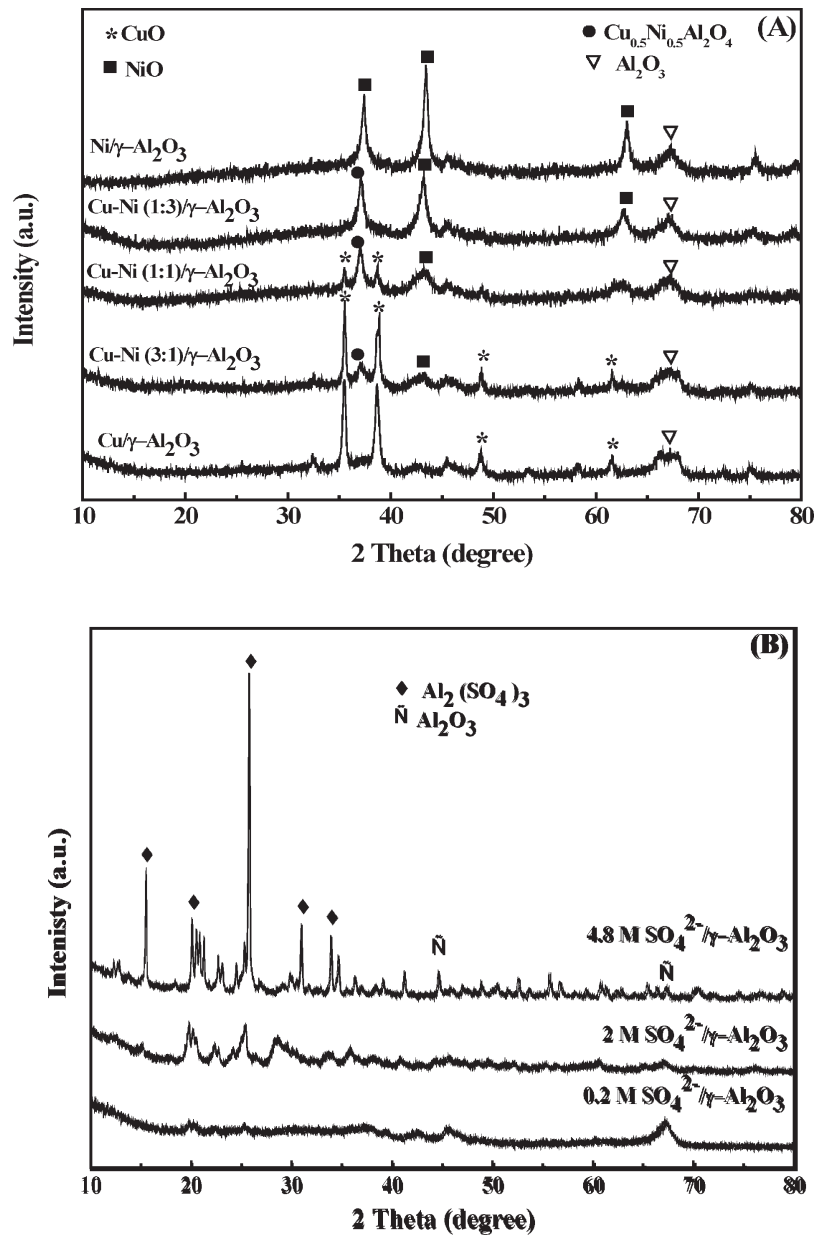

Fig. $1-X R D$ patterns of (A) $\mathrm{Cu} / \gamma-\mathrm{Al}_{2} \mathrm{O}_{3}, \mathrm{Ni} / \gamma-\mathrm{Al}_{2} \mathrm{O}_{3}$ and $\mathrm{Cu}-\mathrm{Ni} / \gamma-\mathrm{Al}_{2} \mathrm{O}_{3}$ catalysts (B) $\mathrm{SO}_{4}^{2-} / \gamma \mathrm{Al}_{2} \mathrm{O}_{3}$ catalysts

shows sharp reflections at $2 \theta=37.3^{\circ}, 43.2^{\circ}$ and $62.8^{\circ}$, which corresponds to $\mathrm{NiO}$ (JCPDS: 44-1159), and reflects typical rhombohedral structure. For $\mathrm{Cu}-\mathrm{Ni} / \gamma-\mathrm{Al}_{2} \mathrm{O}_{3}$ bimetallic catalysts, additional peaks were observed at $2 \theta=36.9^{\circ}, 43.2^{\circ}$ and $62.8^{\circ}$ other than $\mathrm{CuO}$. The diffraction peak at $2 \theta=36.9^{\circ}$ corresponds to the mixed metal oxide phase $\mathrm{Cu}_{05} \mathrm{Ni}_{05} \mathrm{Al}_{2} \mathrm{O}_{4}$ (JCPDS: 78-1603), and peaks at $2 \theta=43.2^{\circ}$ and $62.8^{\circ}$ correspond to $(012)$ and $(110)$ planes of NiO (JCPDS: 44-1159). The XRD pattern of $\mathrm{Cu}-\mathrm{Ni}$ bimetallic catalysts shows that the intensity of the peaks corresponding to the mixed metal oxide phase $\left(\mathrm{Cu}_{05} \mathrm{Ni}_{0.5} \mathrm{Al}_{2} \mathrm{O}_{4}\right)$ and $\mathrm{NiO}$ increased with Ni loading. The intensity of the peaks corresponding to $\mathrm{CuO}$ and $\mathrm{NiO}$ for bimetallic catalysts were low and broad compared to that for monometallic catalysts. This result indicates better dispersion of metal on alumina support for bimetallic catalysts.

XRD patterns of sulphated alumina catalysts are shown in Fig. 1B. For $0.2 \mathrm{M} \mathrm{SO}_{4}^{2-} / \gamma-\mathrm{Al}_{2} \mathrm{O}_{3}$ catalyst, the peaks obtained at $2 \theta=44.6^{\circ}$ and $67.4^{\circ}$ correspond to alumina, which confirms the presence of the monoclinic phase of $\mathrm{Al}_{2} \mathrm{O}_{3}$ (JCPDS: 86-1410).
For this catalyst, no additional peaks were detected for $\mathrm{SO}_{4}^{2-}$ species. However, for $2 \mathrm{M} \mathrm{SO}_{4}{ }^{2-} / \gamma-\mathrm{Al}_{2} \mathrm{O}_{3}$ and $4.8 \mathrm{M} \mathrm{SO}_{4}{ }^{2-} / \gamma-\mathrm{Al}_{2} \mathrm{O}_{3}$ catalysts, an additional peak was obtained at $2 \theta=25.5^{\circ}$ corresponding to $\mathrm{Al}_{2}\left(\mathrm{SO}_{4}\right)_{3}$ (JCPDS: 81-1835). ${ }^{29}$ The intensity of the peak corresponding to $\mathrm{Al}_{2}\left(\mathrm{SO}_{4}\right)_{3}$ increased with the concentration of $\mathrm{SO}_{4}^{2-}$ in the catalyst.

A quantitative estimation of the total acidity of the catalysts based on desorbed ammonia at different temperature is summarized in Table 1. The $\mathrm{NH}_{3}$-TPD profiles (Fig. 2A) of the $\mathrm{Cu} / \gamma-\mathrm{Al}_{2} \mathrm{O}_{3}$, $\mathrm{Ni} / \gamma-\mathrm{Al}_{2} \mathrm{O}_{3}$ and $\mathrm{Cu}-\mathrm{Ni} / \gamma-\mathrm{Al}_{2} \mathrm{O}_{3}$ catalysts shows $\mathrm{NH}_{3}$ desorption peaks in three different temperature regions for all catalysts. The peaks obtained at $80-250{ }^{\circ} \mathrm{C}$ are attributed to desorption of ammonia from weak acidic sites, and the peaks at $250-500{ }^{\circ} \mathrm{C}$ refer to moderate strength acidic sites on the catalysts. The high temperature $\left(>500{ }^{\circ} \mathrm{C}\right)$ peaks indicate that strong acid sites exist on the catalysts. ${ }^{30,31}$ The $\mathrm{NH}_{3}$-TPD profile of the $\gamma-\mathrm{Al}_{2} \mathrm{O}_{3}$ surface displays the peaks in all three temperature ranges, and suggests the high acidic strength of $1.203 \mathrm{mmol} \mathrm{NH}_{3} \mathrm{~g}_{\text {cat. }}{ }^{-1}$. The results reported in Table 1 suggest that the acidic strength of the catalysts had decreased significantly after metal impregnation. Monometallic and bime-
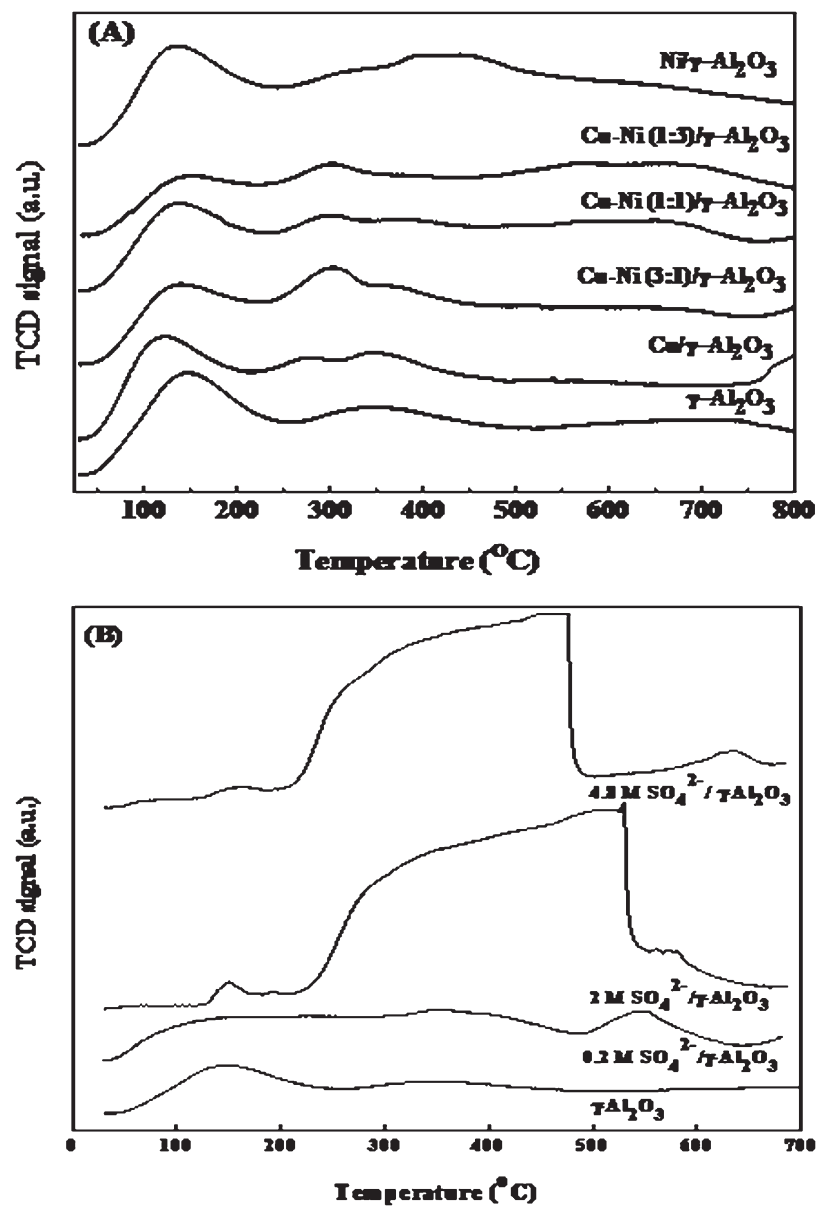

Fig. 2 - $\mathrm{NH}_{3}-\mathrm{TPD}$ profiles of (A) $\gamma-\mathrm{Al}_{2} \mathrm{O}_{3}, \mathrm{Cu} / \gamma-\mathrm{Al}_{2} \mathrm{O}_{3} \mathrm{Ni} / \gamma-\mathrm{Al}_{2} \mathrm{O}_{3}$ and $\mathrm{Cu}-\mathrm{Ni} / \gamma-\mathrm{Al}_{2} \mathrm{O}_{3}$ catalysts $(\mathrm{B}) \mathrm{SO}_{4}^{2-} / \gamma-\mathrm{Al}_{2} \mathrm{O}_{3}$ catalysts 
tallic catalyst samples have acidity in the range of $0.407-0.562 \mathrm{mmol} \mathrm{NH}_{3} \mathrm{~g} \mathrm{cat}^{-1}$ which is lower than the acidity $\left(1.203 \mathrm{mmol} \mathrm{NH}_{3} \mathrm{~g}^{\prime} \mathrm{cat}^{-1}\right)$ of $\gamma-\mathrm{Al}_{2} \mathrm{O}_{3}$.

The $\mathrm{NH}_{3}$-TPD results obtained for the $\mathrm{SO}_{4}^{2-} / \gamma-\mathrm{Al}_{2} \mathrm{O}_{3}$ catalysts and $\gamma-\mathrm{Al}_{2} \mathrm{O}_{3}$ are shown in Fig. 2B. The TPD profiles obtained for all the catalysts indicate widely distributed surface acidic strength. ${ }^{11}$ For $0.2 \mathrm{M} \mathrm{SO}_{4}{ }^{2-} / \gamma-\mathrm{Al}_{2} \mathrm{O}_{3}$ catalyst, the desorption peak was detected at high temperature $\left(500-750{ }^{\circ} \mathrm{C}\right)$, which suggests the existence of strong acid sites on the catalysts. For $2 \mathrm{M} \mathrm{SO}_{4}^{2-} / \gamma-\mathrm{Al}_{2} \mathrm{O}_{3}$ and $4.8 \mathrm{M} \mathrm{SO}_{4}^{2-} / \gamma-\mathrm{Al}_{2} \mathrm{O}_{3}$ catalysts, a major broad peak with high intensity was detected at $250-500{ }^{\circ} \mathrm{C}$, indicating medium acidic sites. ${ }^{27}$ The intensity of the peak obtained for both these catalysts is almost identical. Similar results have also been reported by Yang et al..$^{29}$ They found that the intensity of strong acidic peaks remained unchanged for $\left[\mathrm{H}_{2} \mathrm{SO}_{4}\right] \geq 2.4 \mathrm{M}$. The estimated total acidity of the catalysts showed that the impregnations of $\mathrm{H}_{2} \mathrm{SO}_{4}$ on $\gamma-\mathrm{Al}_{2} \mathrm{O}_{3}$ resulted in an increase in acidity (Table 1). The acidity of $0.2 \mathrm{M} \mathrm{SO}_{4}^{2-} / \gamma-\mathrm{Al}_{2} \mathrm{O}_{3}$ is higher $\left(1.32 \mathrm{mmol} \mathrm{NH}_{3} \mathrm{~g} \mathrm{cat}^{-1}\right)$ than that of $\gamma-\mathrm{Al}_{2} \mathrm{O}_{3}\left(1.203 \mathrm{mmol} \mathrm{NH}_{3}, \mathrm{~g} \mathrm{cat}^{-1}\right)$. The highest acidity of $2.51 \mathrm{mmol} \mathrm{NH}_{3} \mathrm{~g}^{\text {cat }}{ }^{-1}$ was obtained for $2 \mathrm{M} \mathrm{SO}_{4}^{2-} / \gamma-\mathrm{Al}_{2} \mathrm{O}_{3}$ catalyst.

The FT-IR spectra (Fig. 3) of sulphated alumina catalysts displayed the bands in the wave number range of $3000-3400 \mathrm{~cm}^{-1}$ and at $\sim 1632 \mathrm{~cm}^{-1}$ corresponding to the hydroxyl groups. ${ }^{32}$ However, the bands at $\sim 1100 \mathrm{~cm}^{-1}$ correspond to the symmetric vibrations of $\mathrm{S}=\mathrm{O}$ group. ${ }^{33}$ Increased sulphate content enhances the intensity of the bands and shifts the characteristic vibration of $\mathrm{S}=\mathrm{O}$ groups towards higher values $\left(\sim 1200 \mathrm{~cm}^{-1}\right)$. This shift is mostly due to the formation of new sulphate species in case of such sulphate loading. ${ }^{34}$

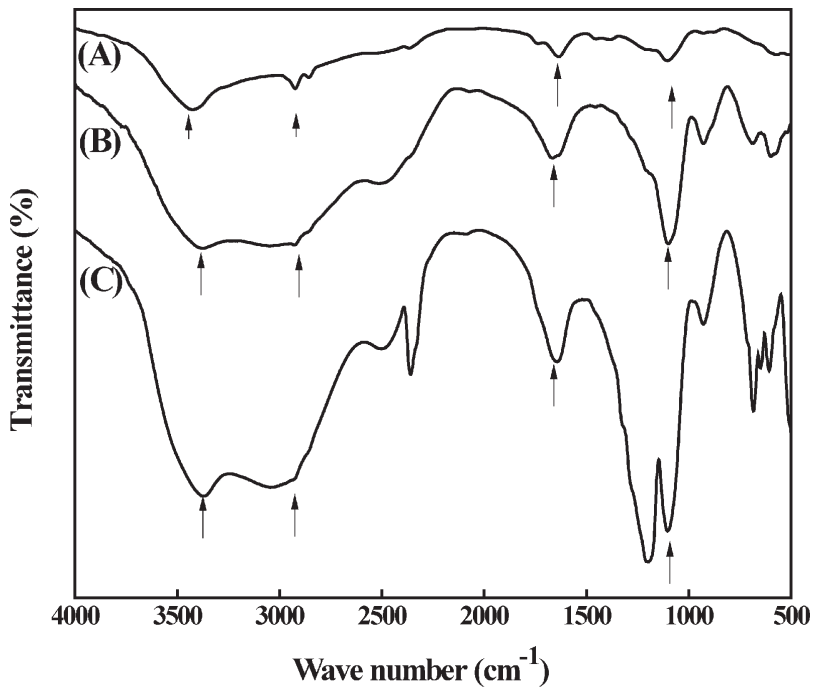

Fig. 3 - FT-IR patterns of $\mathrm{SO}_{4}^{2-} / \gamma-\mathrm{Al}_{2} \mathrm{O}_{3}$ catalysts (A) $0.2 \mathrm{M}$ $\mathrm{SO}_{4}^{2-} / \gamma-\mathrm{Al}_{2} \mathrm{O}_{3}$ (B) $2 \mathrm{M} \mathrm{SO}_{4}^{2-1 / \gamma-\mathrm{Al}_{2} \mathrm{O}_{3}}$ (C) $4.8 \mathrm{M}$ $\mathrm{SO}_{4}^{2-} / \gamma-\mathrm{Al}_{2} \mathrm{O}_{3}$

\section{Catalytic evaluation}

To verify the homogeneous reaction, esterification reactions were performed in the absence of catalysts (blank test) by keeping the other reaction conditions constant, and the results show that, in the absence of catalyst, glycerol conversion is significant $(82 \%)$ (Table 2). In the blank test, MAG $(71.5 \%)$ and DAG $(26.5 \%)$ were obtained as the two main reaction products. However, a trace amount of TAG (2\%) was also detected. Depending on the catalyst used, this reaction is accelerated in different ways; as a result, the glycerol conversions and product selectivity obtained are quite different for different catalysts. However, MAG, DAG and TAG are the main reaction products, these products

Table 2 -Catalytic behavior for esterification of glycerol with acetic acid ${ }^{a}$

\begin{tabular}{|c|c|c|c|c|c|c|}
\hline \multirow{2}{*}{ Catalyst } & \multirow{2}{*}{$\begin{array}{l}\text { Glycerol conversion } \\
(\%)\end{array}$} & \multicolumn{3}{|c|}{ Selectivity (\%) } & \multirow{2}{*}{ Yield TAG (\%) } & \multirow{2}{*}{$\begin{array}{l}\text { Initial reaction rate } \\
\left(\mathrm{mmol}_{\text {gly }} \mathrm{g} \mathrm{cat}^{-1} \mathrm{~h}^{-1}\right)\end{array}$} \\
\hline & & MAG & DAG & TAG & & \\
\hline Blank & 82 & 71.5 & 26.5 & 2.0 & 1.7 & - \\
\hline$\gamma-\mathrm{Al}_{2} \mathrm{O}_{3}$ & 82 & 86.7 & 12.9 & 0.5 & 0.4 & 0.90 \\
\hline $\mathrm{Cu} / \gamma-\mathrm{Al}_{2} \mathrm{O}_{3}$ & 84 & 70.7 & 27.0 & 2.3 & 1.9 & 0.99 \\
\hline $\mathrm{Cu}-\mathrm{Ni}(3: 1) / \gamma-\mathrm{Al}_{2} \mathrm{O}_{3}$ & 89 & 75.4 & 23.2 & 1.4 & 1.2 & 3.11 \\
\hline $\mathrm{Cu}-\mathrm{Ni}(1: 1) / \gamma-\mathrm{Al}_{2} \mathrm{O}_{3}$ & 94 & 77.6 & 21.2 & 1.2 & 1.1 & 2.16 \\
\hline $\mathrm{Cu}-\mathrm{Ni}(1: 3) / \gamma-\mathrm{Al}_{2} \mathrm{O}_{3}$ & 97 & 68.9 & 28.5 & 2.5 & 2.5 & 2.32 \\
\hline $\mathrm{Ni} / \gamma-\mathrm{Al}_{2} \mathrm{O}_{3}$ & 97 & 68.9 & 28.4 & 2.6 & 2.6 & 1.79 \\
\hline $0.2 \mathrm{M} \mathrm{SO}_{4}{ }^{2-} / \gamma-\mathrm{Al}_{2} \mathrm{O}_{3}$ & 97 & 30.5 & 53.6 & 15.9 & 15.5 & 3.61 \\
\hline $2 \mathrm{M} \mathrm{SO}_{4}{ }^{2-} / \gamma-\mathrm{Al}_{2} \mathrm{O}_{3}$ & 97 & 27.0 & 49.9 & 23.1 & 22.5 & 4.22 \\
\hline $4.8 \mathrm{M} \mathrm{SO}_{4}{ }^{2-} / \gamma-\mathrm{Al}_{2} \mathrm{O}_{3}$ & 97 & 33.0 & 48.8 & 18.2 & 17.7 & 3.90 \\
\hline
\end{tabular}

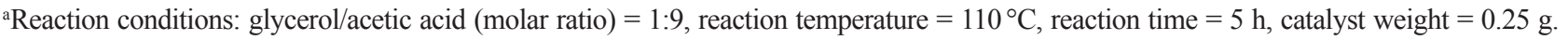

${ }^{b}$ Initial reaction rate is calculated for all catalysts after $0.5 \mathrm{~h}$ of reaction. 
formed according to the reaction scheme reported earlier. ${ }^{3,7}$ In the presence of catalysts, the reaction path of esterification of glycerol involves the conversion of glycerol to MAG, whereas DAG and TAG form through consecutive acetylation reaction. ${ }^{23}$ The glycerol conversion with the sulphated alumina catalyst is highest (97\%) and the effect of the glycerol conversion with the concentration of sulphate species is almost negligible. Among all the $\gamma-\mathrm{Al}_{2} \mathrm{O}_{3}$ supported metal oxide catalysts, $\mathrm{Ni} / \gamma-\mathrm{Al}_{2} \mathrm{O}_{3}$ and $\mathrm{Cu}-\mathrm{Ni}(1: 3) / \gamma-\mathrm{Al}_{2} \mathrm{O}_{3}$ catalyst shows the highest glycerol conversion of $97 \%$. Similar results have been reported earlier for hydrogenolysis of glycerol. ${ }^{35}$ This result demonstrates that the impregnation of metal has a positive effect on the glycerol esterification reaction. However, for the $\mathrm{Cu} / \gamma-\mathrm{Al}_{2} \mathrm{O}_{3}$ catalyst, glycerol conversion is low (85\%). In bimetallic catalysts, after increasing the $\mathrm{Ni}$ content in the catalyst, the glycerol conversion increased from $89 \%$ to $97 \%$. Kang et al. ${ }^{36}$ reported that, with increasing nickel content in the $\mathrm{Cu}-\mathrm{Ni} / \gamma-\mathrm{Al}_{2} \mathrm{O}_{3}$ catalysts, the catalytic activity had increased for hydrogenolysis of 1,3-butadiene. By comparing the structural parameter and acidity of the catalysts (Table 1), it can be observed that the catalytic activity is independent of the structural properties and the acidity of supported metal oxide catalysts. ${ }^{9}$ In the presence of $\gamma-\mathrm{Al}_{2} \mathrm{O}_{3}$, glycerol conversion is $82 \%$, which is similar to the conversion obtained for uncatalyzed reaction. This result indicates that $\gamma-\mathrm{Al}_{2} \mathrm{O}_{3}$ itself has no significant catalytic activity for esterification of glycerol with acetic acid.

Variation of glycerol conversion with time for $\mathrm{SO}_{4}^{2-} / \gamma-\mathrm{Al}_{2} \mathrm{O}_{3}$ catalysts is plotted and shown in Fig. 4. The results show that the initial activity of the catalysts passed through maxima with $\mathrm{H}_{2} \mathrm{SO}_{4}$ concentration. After 30 minutes, for $0.2 \mathrm{M} \mathrm{SO}_{4}^{2-} / \gamma-\mathrm{Al}_{2} \mathrm{O}_{3}$ cat-

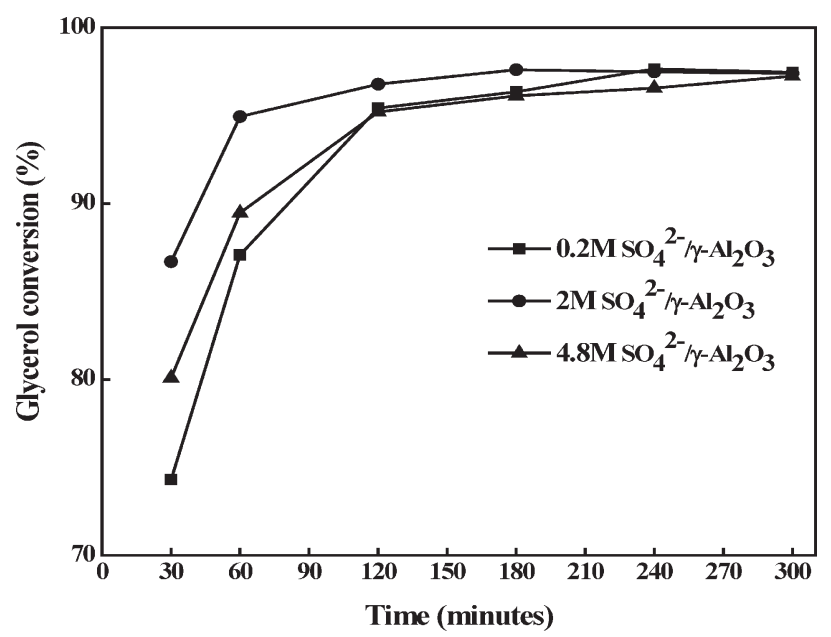

Fig. 4 - Variation of glycerol conversion with time over $\mathrm{SO}_{4}^{2-} / \gamma-\mathrm{Al}_{2} \mathrm{O}_{3}$ catalysts. Reaction conditions: Glycerol/Acetic acid (molar ratio) $=1: 9$, reaction temperature $=110^{\circ} \mathrm{C}$, reaction time $=5 \mathrm{~h}$, catalyst weight $=0.25 \mathrm{~g}$. alysts, glycerol conversion was $\sim 74 \%$, then activity increased to $\sim 87 \%$ for $2 \mathrm{M} \mathrm{SO}_{4}{ }^{2-} / \gamma-\mathrm{Al}_{2} \mathrm{O}_{3}$ catalysts, and further decreased to $\sim 80 \%$ in case of $4.8 \mathrm{M}$ $\mathrm{SO}_{4}^{2-} \gamma-\mathrm{Al}_{2} \mathrm{O}_{3}$ catalysts. The initial increase in activity with the increase in concentration of $\mathrm{H}_{2} \mathrm{SO}_{4}$ can be explained by kinetic effect. While at higher concentrations, the decrease in activity might be due to the limitations of internal diffusion in the catalyst. ${ }^{3}$ Glycerol conversion increased rapidly in the first hour, after which the rate of increase slowed down. For all three $\mathrm{SO}_{4}^{2-} / \gamma-\mathrm{Al}_{2} \mathrm{O}_{3}$ catalysts, glycerol conversion exceeded $85 \%$ within $1 \mathrm{~h}$ of the reaction, and reached $97 \%$ after $5 \mathrm{~h}$ of reaction. The $2 \mathrm{M}$ $\mathrm{SO}_{4}^{2-} / \gamma-\mathrm{Al}_{2} \mathrm{O}_{3}$ catalysts show the best catalytic activity and $97^{2} \%$ glycerol conversion is achieved after $2 \mathrm{~h}$ of reaction. The results obtained for sulphated alumina catalysts can be correlated with the total acidity of the catalysts. The highest activity of $2 \mathrm{M}$ $\mathrm{SO}_{4}^{2-} / \gamma-\mathrm{Al}_{2} \mathrm{O}_{3}$ catalysts is due to the high acidic strength of $2.51 \mathrm{mmol} \mathrm{NH}_{3} \mathrm{~g}$ cat. $^{-1}$ (Table 1).

The initial reaction rate was calculated for all the catalysts after $0.5 \mathrm{~h}$ of the reaction and the values obtained are shown in Table 2. The calculated reaction rate is in the range of $0.9-4.22 \mathrm{mmol}_{\mathrm{gly}} \mathrm{g} \mathrm{cat}^{-1} \mathrm{~h}^{-1}$. The highest initial reaction rate of $4.22 \mathrm{mmol}_{\text {gly }} \mathrm{g} \mathrm{cat}^{-1} \mathrm{~h}^{-1}$ was obtained for $2 \mathrm{M} \mathrm{SO}_{4}{ }^{2-} / \gamma-\mathrm{Al}_{2} \mathrm{O}_{3}$ catalyst.

Fig. 5 compares the glycerol conversion with time for $\mathrm{Ni} / \gamma-\mathrm{Al}_{2} \mathrm{O}_{3}, 2 \mathrm{M} \mathrm{SO}_{4}^{2-} / \gamma-\mathrm{Al}_{2} \mathrm{O}_{3}$ catalyst and uncatalyzed reaction. It can be observed that, in the presence of catalyst, glycerol conversion is significantly higher than the uncatalyzed reaction. Whereas the glycerol conversion stabilized at $97 \%$ for $\mathrm{Ni} / \gamma-\mathrm{Al}_{2} \mathrm{O}_{3}$ and $2 \mathrm{M} \mathrm{SO}_{4}{ }^{2-} / \gamma-\mathrm{Al}_{2} \mathrm{O}_{3}$ catalyst after $5 \mathrm{~h}$ of reaction, the rate of reaction was significantly higher with $2 \mathrm{M} \mathrm{SO}_{4}^{2-} / \gamma-\mathrm{Al}_{2} \mathrm{O}_{3}$ catalyst. For $2 \mathrm{M}$ $\mathrm{SO}_{4}^{2-} / \gamma-\mathrm{Al}_{2} \mathrm{O}_{3}$ catalyst, $97 \%$ glycerol conversion

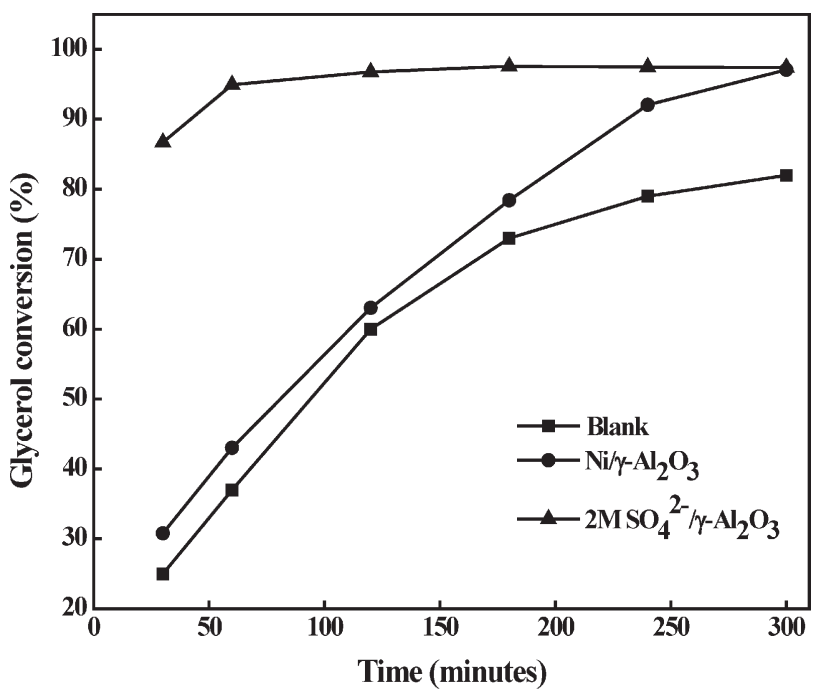

Fig. 5-Comparison of glycerol conversion with time over different catalysts. Reaction conditions: Glycerol/Acetic acid $($ molar ratio $)=1: 9$, reaction temperature $=110^{\circ} \mathrm{C}$, reaction time $=5 \mathrm{~h}$, catalyst weight $=0.25 \mathrm{~g}$. 
was achieved after $2 \mathrm{~h}$ of reaction, while for $\mathrm{Ni} / \gamma-\mathrm{Al}_{2} \mathrm{O}_{3}$ catalyst, it took about $4 \mathrm{~h}$ to reach $90 \%$ glycerol conversion. This result follows the calculated reaction rate data (Table 2).

For all the catalysts, the main reaction products are MAG, DAG and TAG. Table 2 shows the selectivity to MAG, DAG and TAG obtained after $5 \mathrm{~h}$ of reaction. The results demonstrate that the catalyst used affects the product selectivity. The results obtained over metal-impregnated alumina $(\mathrm{Cu}$ or $\mathrm{Ni}$ and $\mathrm{Cu}-\mathrm{Ni}$ ) suggest that these catalysts have a slightly positive effect on the product selectivity. Similar product distribution was observed for $\mathrm{Ni} / \gamma-\mathrm{Al}_{2} \mathrm{O}_{3}$ and $\mathrm{Cu}: \mathrm{Ni}(1: 3) / \gamma-\mathrm{Al}_{2} \mathrm{O}_{3}$ catalyst, and after $5 \mathrm{~h}$ of reaction show $\sim 68.9 \%, \sim 28.5 \%$ and $\sim 2.5 \%$ selectivity to MAG, DAG and TAG, respectively. This result suggests that $\mathrm{Ni} / \gamma-\mathrm{Al}_{2} \mathrm{O}_{3}$ and $\mathrm{Cu}: \mathrm{Ni}(1: 3) / \gamma-\mathrm{Al}_{2} \mathrm{O}_{3}$ catalyst is more selective to MAG but not very effective for successive acetylation of MAG to DAG and TAG.

The product selectivity obtained over sulphated alumina (Fig. 6) show that sulphation has a significant effect on the selectivity of products. For all the sulphated catalysts, DAG and TAG selectivity increased significantly with time at the expense of MAG. The $2 \mathrm{M} \mathrm{SO}_{4}^{2-} / \gamma-\mathrm{Al}_{2} \mathrm{O}_{3}$ catalyst showed the best results in terms of product selectivity and for this catalyst, MAG, DAG and TAG selectivity were $27.0 \%, 49.9 \%$ and $23.1 \%$, respectively. This result suggests that successive acetylation of MAG is favorable in the presence of sulphated alumina. The results obtained over $2 \mathrm{M} \mathrm{SO}_{4}^{2-} / \gamma-\mathrm{Al}_{2} \mathrm{O}_{3}$ catalyst are comparable with the result reported in the literature. ${ }^{3,8}$ However, in this study, the obtained selectivity to TAG is significantly higher $(23.1 \%)$. Previously, Liao et al. ${ }^{17}$ reported $\sim 100 \%$ glycerol conversion with $\sim 25 \%$ selectivity to TAG after $4 \mathrm{~h}$ of reaction over Amberlyst-35 catalyst. Comparing our results with the results reported by Liao et al. ${ }^{17}$, it could be clearly observed that over $2 \mathrm{M}$ $\mathrm{SO}_{4}^{2-} / \gamma-\mathrm{Al}_{2} \mathrm{O}_{3}$ catalyst, $97 \%$ glycerol conversion with $23 \%$ selectivity to TAG was obtained in the presence of lower catalyst concentration.

The product distribution obtained over sulphated alumina catalysts suggests that DAG and TAG selectivity had an increasing trend, whereas MAG selectivity had a decreasing trend with reaction time. This suggests that, initially, glycerol converted to MAG, and as the reaction progressed, MAG further converted to DAG and TAG through successive acetylation reaction. However, the feasibility of this consecutive acetylation reaction depends extremely on the type of catalysts used. The $2 \mathrm{M}$ $\mathrm{SO}_{4}^{2-} / \gamma-\mathrm{Al}_{2} \mathrm{O}_{3}$ catalyst showed the highest selectivity to DAG (49.9\%) and TAG (23.1\%) after $5 \mathrm{~h}$ of reaction. The schematic diagram of the reaction pathways is shown in Fig. 7.
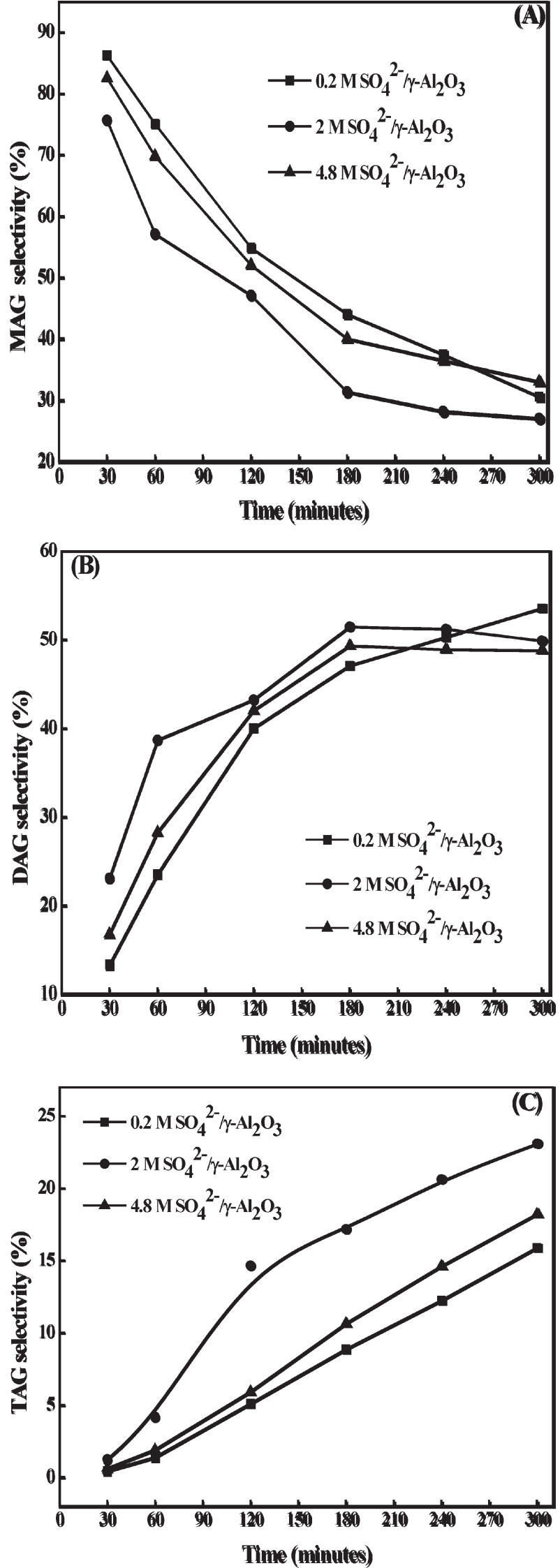

Fig. 6 - Variation of MAG, DAG and TAG selectivity with time for $\mathrm{SO}_{4}^{2-} / \gamma-\mathrm{Al}_{2} \mathrm{O}_{3}$ catalysts Reaction conditions: Glycerol/ Acetic acid (molar ratio) $=1: 9$, reaction temperature $=110^{\circ} \mathrm{C}$, reaction time $=5 \mathrm{~h}$, catalyst weight $=0.25 \mathrm{~g}$. 


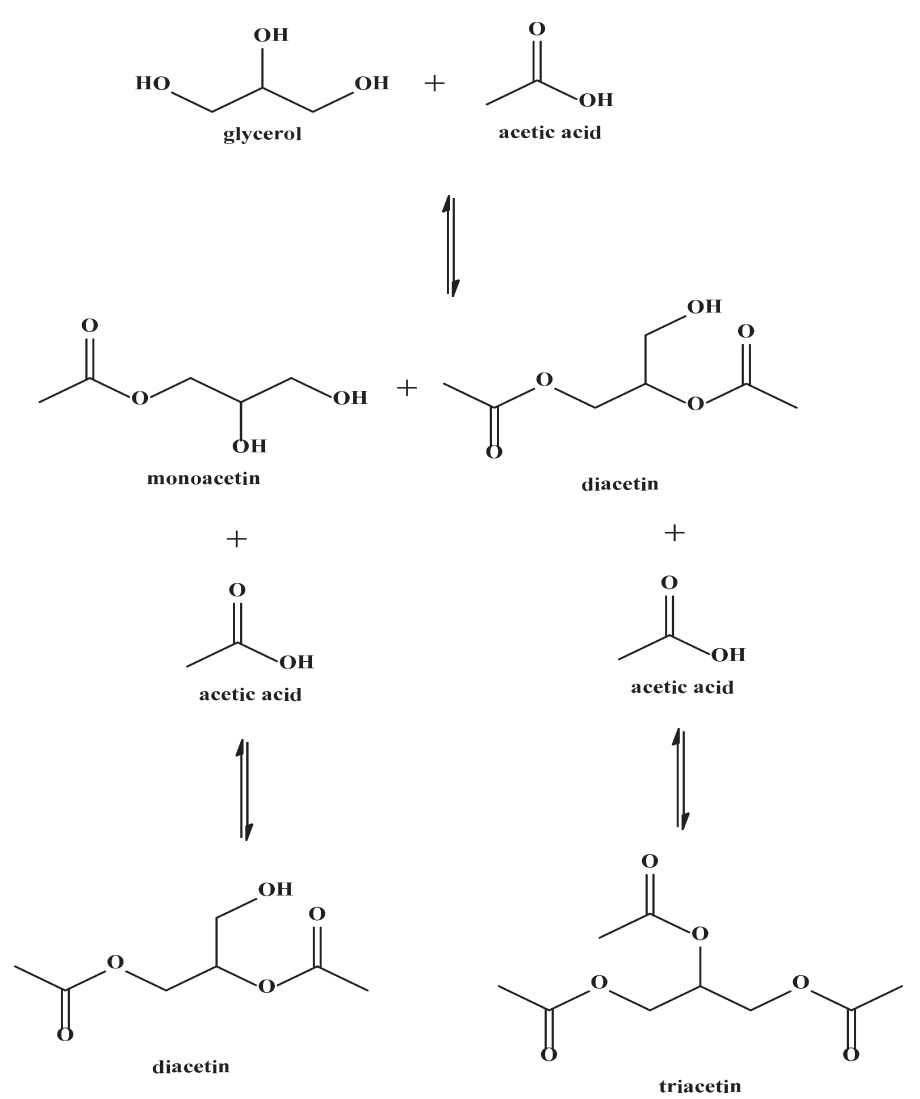

Fig. 7 - Reaction pathway for acetylation of glycerol over $2 \mathrm{M} \mathrm{SO}_{4}^{2-}$ $\gamma-\mathrm{Al}_{2} \mathrm{O}_{3}$ catalyst

To verify the effect of bare $\mathrm{H}_{2} \mathrm{SO}_{4}$ for esterification of glycerol, an experiment was conducted with $\mathrm{H}_{2} \mathrm{SO}_{4}$ instead of using $2 \mathrm{M} \mathrm{SO}_{4}^{2-} / \gamma-\mathrm{Al}_{2} \mathrm{O}_{3}$ as catalyst, maintaining all other reaction conditions constant. The results obtained are shown in Table 3. The results demonstrate that, in the presence of $\mathrm{H}_{2} \mathrm{SO}_{4}, 84 \%$ glycerol conversion was achieved after $5 \mathrm{~h}$ of reaction, and the main acetylation products were MAG and DAG. Moreover, the selectivity to TAG was almost negligible $(0.8 \%)$, while the selectivity to MAG and DAG was $38.1 \%$ and $68.1 \%$, respectively. This result agrees with an earlier report. ${ }^{37}$

The best results obtained over $2 \mathrm{M} \mathrm{SO}_{4}^{2-} / \gamma-\mathrm{Al}_{2} \mathrm{O}_{3}$ catalyst was also compared with the catalytic activity of other sulphated catalysts reported in literature, and the comparison data are presented in Table 3. It can be observed that sulphated alumina catalysts show much higher selectivity to more desirable DAG and TAG.

\section{Stability and reusability tests}

Deactivation behavior and reusability of $\mathrm{Ni} / \gamma$ $\mathrm{Al}_{2} \mathrm{O}_{3}$ and $2 \mathrm{M} \mathrm{SO}_{4}{ }^{2-} / \gamma-\mathrm{Al}_{2} \mathrm{O}_{3}$ catalysts were examined at $110^{\circ} \mathrm{C}$ and atmospheric pressure with a feed mixture containing glycerol and acetic acid (1:9 mole ratio) for $5 \mathrm{~h}$. Prior to each cycle of the experiment, the catalyst was separated by centrifugation, washed with deionised water, and then dried over night at $110{ }^{\circ} \mathrm{C}$. The results obtained for three successive reactions are summarized in Table 4. For $\mathrm{Ni} / \gamma-\mathrm{Al}_{2} \mathrm{O}_{3}$ catalyst, a loss in catalytic activity was observed in every consecutive run, and glycerol conversion reduced from $97 \%$ to $88 \%$ in successive cycles, while the product selectivity remained almost unchanged. This decrease in conversion was due to the leaching $(\sim 10-15 \%)$ of nickel metal into the liquid phase confirmed by the ICP-MS analysis. For $2 \mathrm{M} \mathrm{SO}_{4}^{2-} / \gamma-\mathrm{Al}_{2} \mathrm{O}_{3}$, no loss in catalytic activity was observed and glycerol conversion was maintained at $97 \%$ even after cycle- 2 . The selectivity of products was also consistent with the successive recycle experiments. In contrast to these results, the

Table 3 -Catalytic behavior over different catalysts

\begin{tabular}{|c|c|c|c|c|c|c|}
\hline \multirow{2}{*}{ Catalyst } & \multirow{2}{*}{$\begin{array}{c}\text { Glycerol } \\
\text { conversion (\%) }\end{array}$} & \multicolumn{3}{|c|}{ Selectivity (\%) } & \multirow{2}{*}{ Yield of TAG (\%) } & \multirow{2}{*}{ Reference } \\
\hline & & MAG & DAG & TAG & & \\
\hline $0.2 \mathrm{M} \mathrm{SO}_{4}{ }^{2-} / \gamma-\mathrm{Al}_{2} \mathrm{O}_{3}{ }^{\mathrm{a}}$ & 97 & 30.5 & 53.5 & 15.8 & 15.5 & This study \\
\hline $2 \mathrm{M} \mathrm{SO}_{4}{ }^{2-} / \gamma-\mathrm{Al}_{2} \mathrm{O}_{3}{ }^{\mathrm{a}}$ & 97 & 27.0 & 49.9 & 23.1 & 22.5 & This study \\
\hline $4.8 \mathrm{M} \mathrm{SO}_{4}{ }^{2-} / \gamma-\mathrm{Al}_{2} \mathrm{O}_{3}{ }^{\mathrm{a}}$ & 97 & 32.9 & 48.8 & 18.2 & 17.7 & This study \\
\hline $\mathrm{H}_{2} \mathrm{SO}_{4}{ }^{\mathrm{a}}$ & 84 & 38.1 & 61.1 & 0.8 & 0.6 & This study \\
\hline $\mathrm{H}_{2} \mathrm{SO}_{4}{ }^{\mathrm{b}}$ & 98 & 54 & 27 & Traces & Traces & {$[20]$} \\
\hline Sulphated zirconia $^{c}$ & - & 98 & 2 & Traces & Traces & {$[21]$} \\
\hline Sulphated activated carbon ${ }^{\mathrm{d}}$ & 91 & 38 & 28 & 34 & 31 & [23] \\
\hline
\end{tabular}

a Reaction conditions: glycerol/acetic acid (molar ratio) $=1: 9$, reaction temperature $=110^{\circ} \mathrm{C}$, reaction time $=5 \mathrm{~h}$, catalyst wt. $=0.25 \mathrm{~g}$. ${ }^{b}$ Reaction conditions: glycerol/acetic acid (molar ratio) $=1: 3$, reaction temperature $=60^{\circ} \mathrm{C}$, reaction time $=8 \mathrm{~h}$, catalyst conc. $\left(\mathrm{H}^{+}\right)=0.03 \mathrm{mmol}$.

'Reaction conditions: glycerol reaction temperature $=55^{\circ} \mathrm{C}$, reaction time $=24 \mathrm{~h}$, catalyst weight $=250 \mathrm{mg} / 40 \mathrm{~mL}$ glycerol; monoacetin, $40 \%$, concentration $=32.4 \mathrm{~g} \mathrm{~L}^{-1}$ glycerol.

${ }^{\mathrm{d}}$ Reaction conditions: glycerol/acetic acid (molar ratio) $=1: 9$, reaction temperature $=120^{\circ} \mathrm{C}$, reaction time $=3 \mathrm{~h}$, catalyst wt. $=0.8 \mathrm{~g}$. 
Table 4 -Catalytic behavior of catalyst during recycling experiments ${ }^{a}$

\begin{tabular}{c|l|c|c|c|c}
\hline \multicolumn{1}{c}{ Catalyst } & Experiment & Glycerol conversion (\%) & MAG selectivity (\%) & DAG selectivity (\%) & TAG selectivity (\%) \\
\hline \multirow{2}{*}{$\mathrm{Ni} / \gamma-\mathrm{Al}_{2} \mathrm{O}_{3}$} & Fresh & 97 & 68 & 29 & 3 \\
& Cycle 1 & 92 & 65 & 32 & 3 \\
& Cycle 2 & 88 & 69 & 29 & 2 \\
\hline \multirow{2}{*}{$2 \mathrm{M} \mathrm{SO}_{4}^{2-} / \gamma-\mathrm{Al}_{2} \mathrm{O}_{3}$} & Cycle 1 & 97 & 32 & 47 & 21 \\
& Cycle 2 & 97 & 35 & 46 & 19 \\
& 97 & 35 & 47 & 18 \\
\hline
\end{tabular}

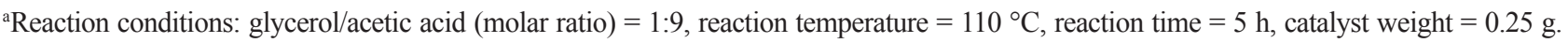

previous studies over sulphated catalysts showed a significant decrease in glycerol conversion and TAG selectivity due to the lower stability of sulphonic species in the reusability test. ${ }^{9,23}$ In this study, the results obtained in the reusability experiment suggest that the $2 \mathrm{M} \mathrm{SO}_{4}^{2-} / \gamma-\mathrm{Al}_{2} \mathrm{O}_{3}$ catalyst was very stable and showed consistent performance in consecutive runs.

\section{Characterization of used catalysts}

To verify the structural stability of the catalysts, samples of the used catalyst were characterized after each experiment. XRD patterns of fresh and used $\mathrm{Ni} / \gamma-\mathrm{Al}_{2} \mathrm{O}_{3}$ catalysts were compared. From Fig. 8 , it can be seen that the intensity of the peaks corresponding to $\mathrm{NiO}$ at $2 \theta=43^{\circ}$ and $37^{\circ}$ had decreased in every successive use. This result suggests the loss of metal from the catalyst surface into the liquid due to leaching during the reaction. To confirm the metal leaching, the reaction mixture was collected after $5 \mathrm{~h}$ of reaction, and the metal content analyzed by ICP-MS analysis. The results obtained

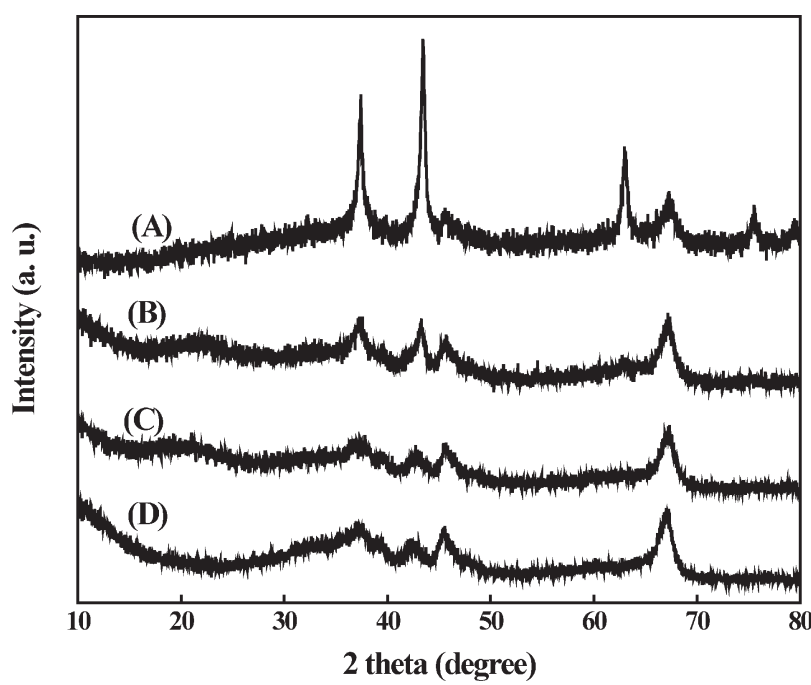

Fig. 8 - XRD patterns of fresh and used $\mathrm{Ni} / \gamma-\mathrm{Al}_{2} \mathrm{O}_{3}$ catalysts, (A) Fresh catalyst, (B) Cycle-1, (C) Cycle-2, (D) Cycle-3

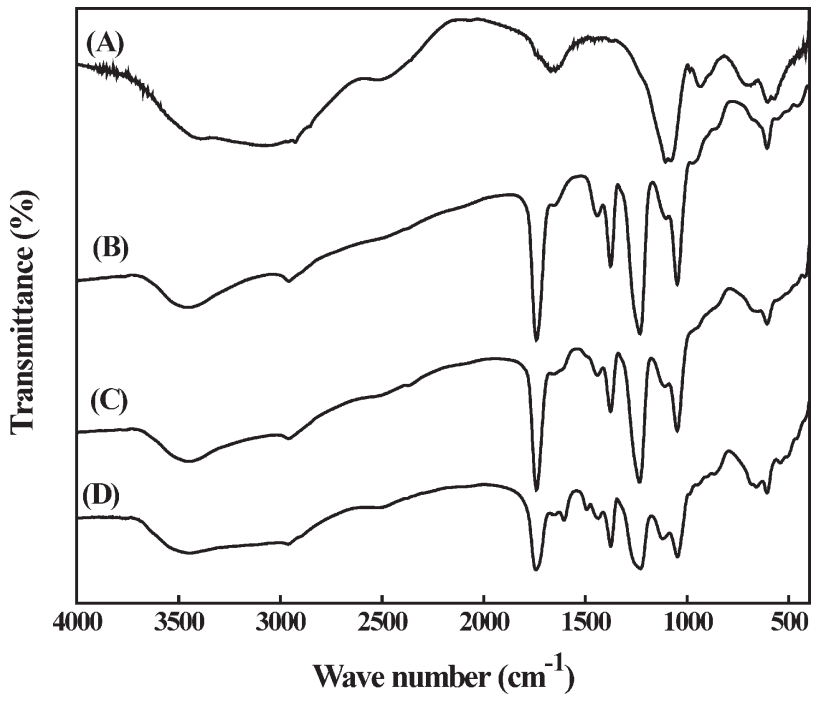

Fig. 9 - FT-IR spectra of fresh and used $2 \mathrm{M} \mathrm{SO}_{4}^{2-} / \gamma-\mathrm{Al}_{2} \mathrm{O}_{3}$ catalyst, (A) Fresh catalyst, (B) Cycle-1, (C) Cycle-2, (D) Cycle-3

confirmed 10-15\% leaching of nickel into the reaction mixture.

The FT-IR spectra of the used $2 \mathrm{M} \mathrm{SO}_{4}{ }^{2-} / \gamma-\mathrm{Al}_{2} \mathrm{O}_{3}$ catalyst after every successive cycle were compared with the FT-IR of the fresh catalyst (Fig. 9). The result shows that the peak corresponding to sulphate species at around $1100 \mathrm{~cm}^{-1}$ is intact in the used catalyst. The additional peaks detected in the used catalyst at $1735 \mathrm{~cm}^{-1}$ correspond to the esters formed in the reaction, and at $1360 \mathrm{~cm}^{-1}$ to alcohols. ${ }^{33}$ Therefore, $2 \mathrm{M} \mathrm{SO}_{4}^{2-} / \gamma-\mathrm{Al}_{2} \mathrm{O}_{3}$ can be considered a stable catalyst for the esterification of glycerol with acetic acid.

\section{Kinetics of glycerol esterification}

Studies of the reaction kinetics for glycerol acetylation are very limited in literature. The kinetic study of the esterification of glycerol with acetic acid catalyzed by $2 \mathrm{M} \mathrm{SO}_{4}^{2-} / \gamma-\mathrm{Al}_{2} \mathrm{O}_{3}$ was carried out by conducting the reaction at different temperatures, and collecting and analyzing reaction samples at regular intervals (Fig. 10 and Fig. 11). Other param- 


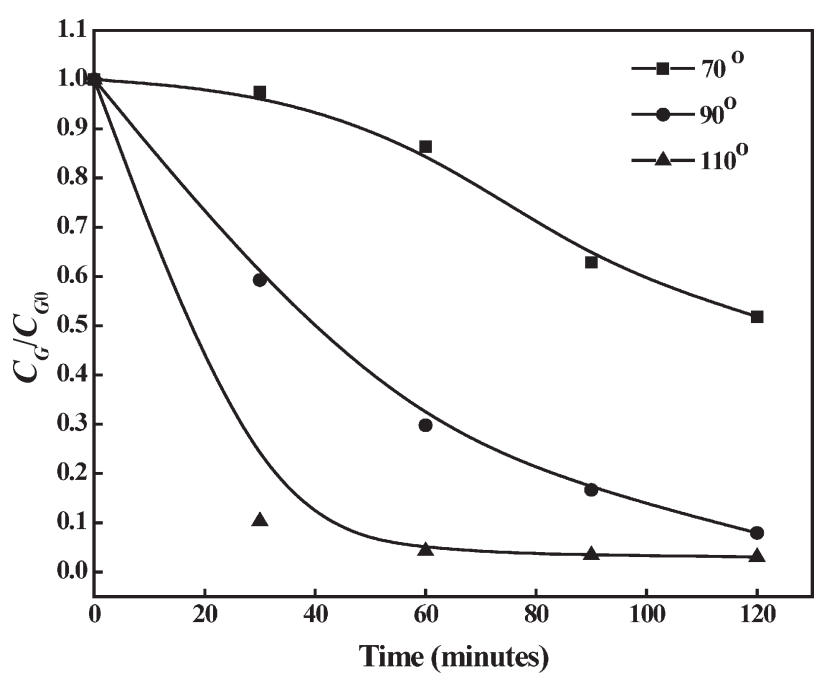

Fig. 10 - Effect of temperature on glycerol concentration for $2 \mathrm{MSO}_{4}^{2-1} \mathrm{\gamma}-\mathrm{Al}_{2} \mathrm{O}_{3}$ catalyst. Reaction conditions: Glycerol/ Acetic acid (molar ratio) $=1: 9$, reaction temperature $=110^{\circ} \mathrm{C}$ reaction time $=5$ h, catalyst weight $=0.25 \mathrm{~g}$.
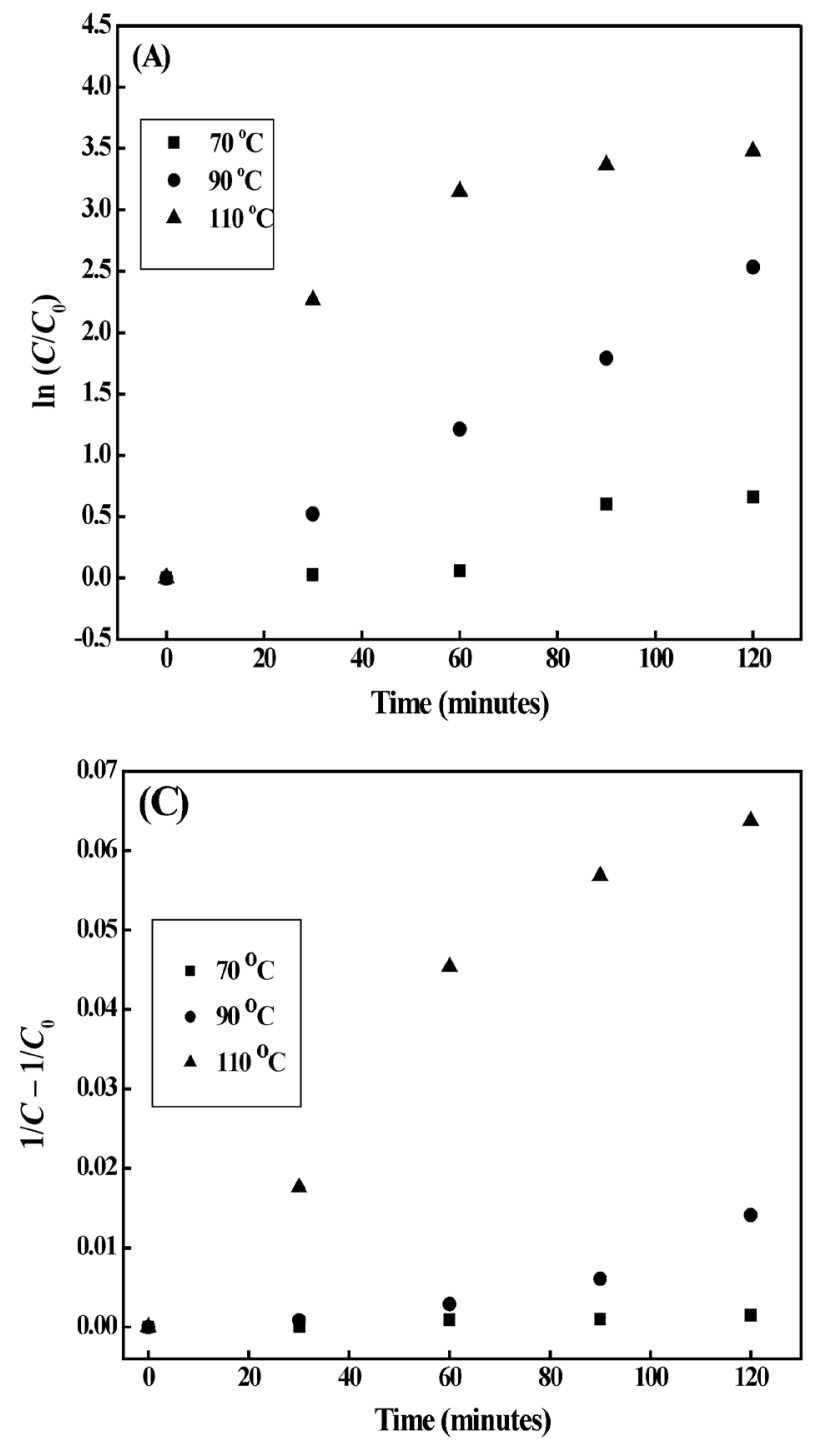

eters like pressure, catalyst loading, and the molar ratio of reactants that may affect kinetics were kept constant. In this study, the Arrhenius equation was employed to determine the rate constant at different temperatures, estimate order of the reaction, and determine the activation energy for the reaction. The glycerol conversion trend obtained over $\mathrm{SO}_{4}^{2-} / \gamma-\mathrm{Al}_{2} \mathrm{O}_{3}$ catalyst suggested that the glycerol concentration changed rapidly in the first $2 \mathrm{~h}$, after which the glycerol concentration stabilized (Fig. 4). Therefore, for the purpose of kinetic study, the reaction was carried out for $2 \mathrm{~h}$, and samples were collected at intervals of 30 minutes. Fig. 10 shows the variation of glycerol concentration with time at different temperatures.

As the esterification reaction was performed by reacting glycerol $(\mathrm{G})$ with excess amounts of acetic acid (A), it could be assumed that the concentration of acetic acid remained almost constant throughout
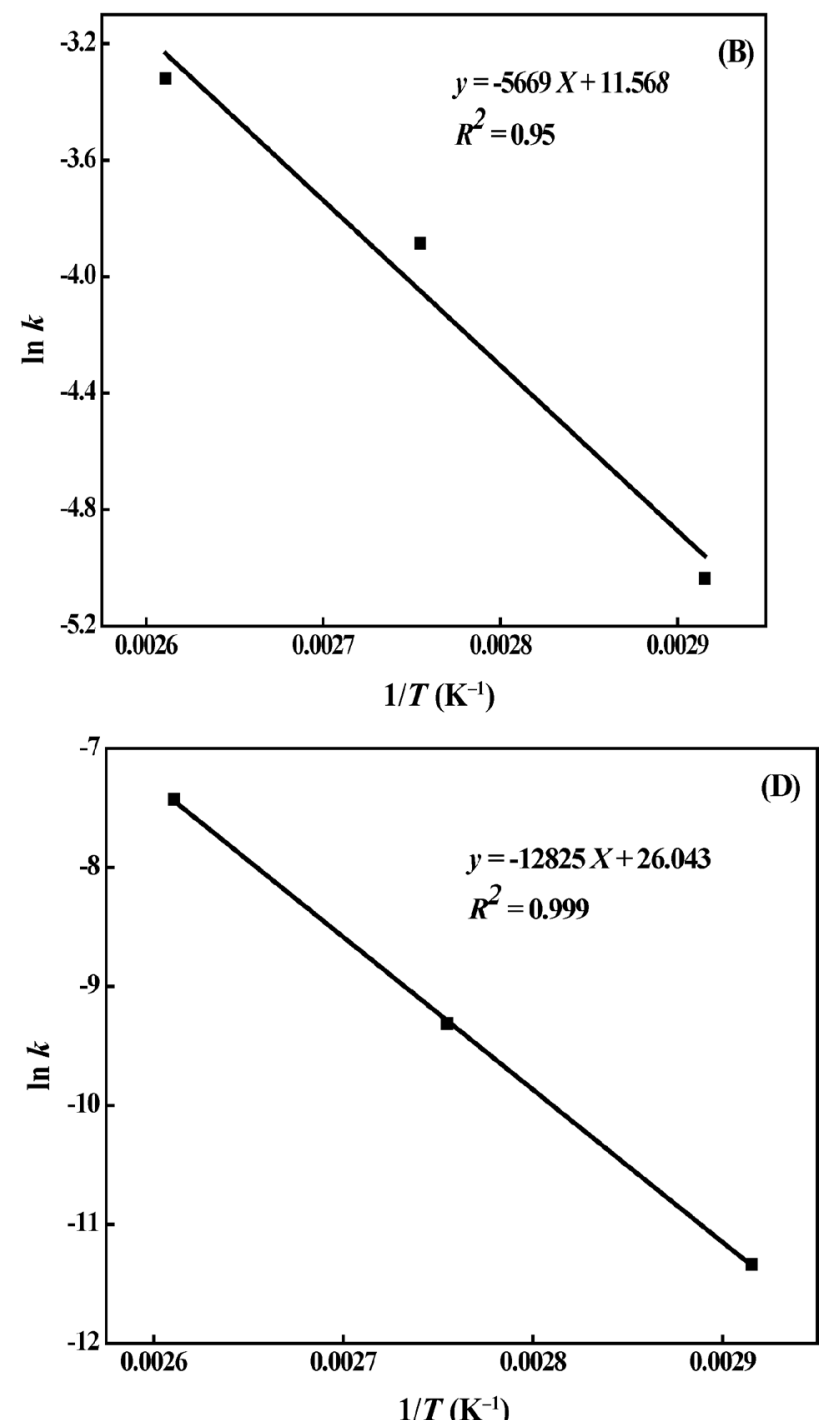

Fig. 11 - Kinetic curves obtained for esterification of glycerol over $2 \mathrm{M} \mathrm{SO}_{4}^{2-} / \gamma-\mathrm{Al}_{2} \mathrm{O}_{3}$ catalyst, (A) \& (B) first-order-dependence; (C) \& (D) second-order-dependence 
the reaction, and the rate could be expressed in terms of the concentration of glycerol alone. The generalized reaction rate can be expressed as

$$
-r_{G}=-\frac{\mathrm{d} C_{G}}{\mathrm{~d} t}=k_{1} C_{G}^{x} C_{A}^{y}
$$

Initially, a pseudo-first-order reaction was assumed. Since acetic acid (A) was present in excess, the concentration of glycerol $(\mathrm{G})$ was the limiting reactant. Therefore, the reaction rate would have depended on the concentration of glycerol, thus, the proposed pseudo-first-order reaction rate can be written as follows:

$$
-r_{G}=-\frac{\mathrm{d} C_{G}}{\mathrm{~d} t}=k_{1} C_{G}
$$

On integration, Eq. (2) reduces to

$$
\ln \left(\frac{C_{G}}{C_{G 0}}\right)=-k_{1} t
$$

The plots of $\ln \left(C_{G} / C_{G 0}\right)$ were obtained, as presented in Fig. 11A, where $C_{G 0}$ is the initial concentration of glycerol and $C_{G}$ is the concentration of glycerol at any given time. The slope of the straight line fit to the curves is $(k)$, the rate constant for the reaction at the particular temperature. The values of rate constant $(k)$ obtained as the slope of each plot and the linearity coefficients are listed in Table 5. The effect of variation of temperature on the rate constant was used to calculate activation energy by employing the Arrhenius equation.

$$
k=A e^{\frac{-E_{a}}{R T}}
$$

Where, $k=$ rate constant, $A=$ Arrhenius constant, $E_{a}=$ Activation energy, $R=$ Universal gas constant, and $T=$ temperature.

Table 5 - Rate constant ( $k$ ) for pseudo-first-order and pseudo-second-order dependence on glycerol conversion

\begin{tabular}{c|c|c|c|c}
\hline \multirow{2}{*}{$\begin{array}{c}\text { Temperature } \\
\left({ }^{\circ} \mathrm{C}\right)\end{array}$} & \multicolumn{2}{|c|}{$\begin{array}{c}\text { Pseudo-first-order } \\
\text { dependence }\end{array}$} & \multicolumn{2}{|c}{$\begin{array}{c}\text { Pseudo-second-order } \\
\text { dependence }\end{array}$} \\
\cline { 2 - 5 } & $k\left(\mathrm{~s}^{-1}\right)$ & regression & $k\left(\mathrm{~L} \mathrm{~mol}^{-1} \mathrm{~s}^{-1}\right)$ & regression \\
\hline 70 & $1.10 \cdot 10^{-4}$ & 0.93 & $1.99 \cdot 10^{-7}$ & 0.95 \\
90 & $3.42 \cdot 10^{-4}$ & 0.99 & $1.50 \cdot 10^{-6}$ & 0.87 \\
110 & $6.04 \cdot 10^{-4}$ & 0.89 & $9.89 \cdot 10^{-6}$ & 0.97 \\
\hline
\end{tabular}

Employing the equation (4), it is clear that the slope of a plot of $(\ln k)$ versus $1 / T$ will be equal to $\left(E_{d} / R\right)$. The plot of $(\ln k)$ versus $1 / T$ is shown in Fig. $11 \mathrm{~B}$. The activation energy of $2 \mathrm{M} \mathrm{SO}_{4}^{2-} / \gamma-\mathrm{Al}_{2} \mathrm{O}_{3}$ catalyzed esterification of glycerol is found to be
$47.13 \mathrm{~kJ} \mathrm{~mol}^{-1}$. From Fig. 11B, it can be seen that, for pseudo-first-order fit, the $R^{2}$ value is $\sim 0.95$.

Further, the pseudo-second-order dependence to glycerol concentration was also studied for better fit. A similar procedure was followed as reported by Goncalves et al. ${ }^{37}$ to test second-order dependence. Assuming a pseudo-second-order dependence to glycerol concentration, the reaction rate can be written as follows:

$$
-r_{G}=-\frac{\mathrm{d} C_{G}}{\mathrm{~d} t}=k_{1} C_{G}^{2}
$$

On integration, Eq. (5) reduces to

$$
\frac{1}{C_{G}}-\frac{1}{C_{G 0}}=k_{2} t
$$

The plots of $\left(1 / C_{G}-1 / C_{G 0}\right)$ versus time were obtained as presented in Fig. $11 \mathrm{C}$, where $C_{G 0}$ is the initial concentration of glycerol, and $C_{G}$ is the concentration of glycerol at any given time. The slope of straight line fit to the curves is $(k)$, the rate constant for the reaction at the particular temperature. The values of rate constant $(k)$ obtained as the slope of each plot and the linearity coefficients are listed in Table 5.

The effect of temperature on rate constant is plotted in Fig. 11D, and activation energy was calculated by employing the Arrhenius equation, as before. The activation energy of $2 \mathrm{M} \mathrm{SO}_{4}^{2-} \gamma-\mathrm{Al}_{2} \mathrm{O}_{3}$ catalyzed esterification of glycerol, assuming pseudo-second-order dependence to glycerol concentration was found to be $106.62 \mathrm{~kJ} \mathrm{~mol}^{-1}$, which is close to the value $\left(101 \mathrm{~kJ} \mathrm{~mol}^{-1}\right)$ reported by Zhou et al. ${ }^{26}$ For pseudo-second-order fit, the $R^{2}$ value was $\sim 99 \%$ (Fig. 11D). This result suggests that the reaction rate to glycerol concentration is pseudo-second-order over $2 \mathrm{M} \mathrm{SO}_{4}{ }^{2-} / \gamma-\mathrm{Al}_{2} \mathrm{O}_{3}$ catalyst.

\section{Conclusions}

$\mathrm{SO}_{4}^{2-} / \gamma-\mathrm{Al}_{2} \mathrm{O}_{3}$ and $\mathrm{Cu}-\mathrm{Ni} / \gamma-\mathrm{Al}_{2} \mathrm{O}_{3}$ catalysts demonstrate good activity towards acetylation of glycerol and yielded MAG, DAG and TAG as the main reaction products. Among all the supported metal catalysts examined, $\mathrm{Cu}-\mathrm{Ni}(1: 3) / \gamma-\mathrm{Al}_{2} \mathrm{O}_{3}$ and $\mathrm{Ni} / \gamma-\mathrm{Al}_{2} \mathrm{O}_{3}$ catalysts showed the maximum glycerol conversion of $97 \%$ after $5 \mathrm{~h}$ of reaction. For these catalysts, MAG, DAG and TAG selectivity was $\sim 68.9 \%, \sim 28.5 \%$ and $\sim 2.5 \%$, respectively. This result suggests that these catalysts were more selective to MAG, but not very effective for successive acetylation of MAG to DAG and TAG.

Sulphation of $\gamma-\mathrm{Al}_{2} \mathrm{O}_{3}$ significantly affected the catalytic activity and product selectivity. For all the $\mathrm{SO}_{4}{ }^{2-} / \gamma-\mathrm{Al}_{2} \mathrm{O}_{3}$ catalysts, $>85 \%$ glycerol conversion was achieved within $1 \mathrm{~h}$ of reaction, and after 
3 h, $97 \%$ glycerol conversion was obtained. For $\mathrm{SO}_{4}{ }^{2-} / \gamma-\mathrm{Al}_{2} \mathrm{O}_{3}$ catalysts, DAG and TAG selectivity showed an increasing trend and selectivity to MAG showed a decreasing trend with time. Product distribution obtained for $\mathrm{SO}_{4}^{2-} / \gamma-\mathrm{Al}_{2} \mathrm{O}_{3}$ catalysts suggested that, initially, glycerol converted to MAG, and as the reaction progressed, MAG further converted to DAG and TAG through successive acetylation reaction over these catalysts. Therefore, $\mathrm{SO}_{4}{ }^{2-} / \gamma-\mathrm{Al}_{2} \mathrm{O}_{3}$ catalysts were highly selective to DAG and TAG. Among all the sulphated catalysts examined, $2 \mathrm{M}$ $\mathrm{SO}_{4}^{2-} / \gamma-\mathrm{Al}_{2} \mathrm{O}_{3}$ catalyst was found to be the most active catalyst resulting in a glycerol conversion of $97 \%$ within $2 \mathrm{~h}$ of reaction. Maximum $\sim 49.9 \%$ selectivity to DAG and $23.1 \%$ selectivity to TAG was obtained over $2 \mathrm{M} \mathrm{SO}_{4}{ }^{2-} / \gamma-\mathrm{Al}_{2} \mathrm{O}_{3}$ catalyst after $5 \mathrm{~h}$ of reaction.

Stability of the catalysts was examined by conducting reusability tests with three consecutive experiments. Over $2 \mathrm{M} \mathrm{SO}_{4}{ }^{2-} / \gamma-\mathrm{Al}_{2} \mathrm{O}_{3}$ catalyst, no loss in activity was observed even after three consecutive experiments, and the catalyst could be considered stable for the esterification of glycerol with acetic acid. Finally, kinetic measurements over $2 \mathrm{M}$ $\mathrm{SO}_{4}^{2-} / \gamma-\mathrm{Al}_{2} \mathrm{O}_{3}$ catalyst showed that the dependence on the reaction rate to glycerol concentration was pseudo-second-order. The activation energy for $2 \mathrm{M}$ $\mathrm{SO}_{4}^{2-} / \gamma-\mathrm{Al}_{2} \mathrm{O}_{3}$ catalyst was found to be $106 \mathrm{~kJ} \mathrm{~mol}^{-1}$.

\section{ACKNOWLEDGEMENTS}

The authors are thankful to the Ministry of Human Resource Development (MHRD), Govt. of India for awarding the fellowship to carry out this work in the Department of Chemical Engineering at the Indian Institute of Technology, Roorkee.

\section{References}

1. Bozell, J., Connecting biomass and petroleum processing with a chemical Bridge, Science 329 (2010) 522. doi: http://dx.doi.org/10.1126/science.1191662

2. Xia, S., Zheng, L., Wang, L., Chena, P., Hou, Z., Hydrogen-free synthesis of 1,2-propanediol from glycerol over $\mathrm{Cu}-\mathrm{Mg}-\mathrm{Al}$ catalysts, RSC Adv. 3 (2013) 16569. doi: http://dx.doi.org/10.1039/c3ra42543f

3. Goncalves, V., Pinto, B., Silva, J., Mota, C., Acetylation of glycerol catalyzed by different solid acids, Catal. Today 133-135 (2008) 673.

doi: http://dx.doi.org/10.1016/j.cattod.2007.12.037

4. Tan, H., Aziz, A., Aroua, M., Glycerol production and its applications as a raw material: A review, Renew. Sust. Energ. Rev. 27 (2013) 118. doi: http://dx.doi.org/10.1016/j.rser.2013.06.035

5. Johnsona, D., Taconi, K., The Glycerin glut: options for the value-added conversion of crude glycerol resulting from biodiesel production, Environ. Progress. 26 (2007) 338. doi: http://dx.doi.org/10.1002/ep.10225
6. Klepacova, K., Mravec, D., Kaszonyi, A., Bajus M., Etherification of glycerol and ethylene glycol by isobutylene, Appl. Catal. A: Gen. 328 (2007) 1. doi: http://dx.doi.org/10.1016/j.apcata.2007.03.031

7. Melero, J., Grieken, R., Morale, G., Paniagua, M., Acidic mesoporous silica for the acetylation of glycerol: synthesis of bioadditives to petrol fuel, Energy and Fuels 21 (2007) 1782. doi: http://dx.doi.org/10.1021/ef060647q

8. Ferreira, P., Fonseca, I., Ramos, A., Vital, J., Castanheiro, $J$., Glycerol acetylation over dodecatungstophosphoric acid immobilized into a silica matrix as catalyst, Appl. Catal. B: Environ. 91 (2009) 416.

doi: http://dx.doi.org/10.1016/j.apcatb.2009.06.009

9. Dosuna-Rodriguez, I., Adriany, C., Gaigneaux, E., Glycerol acetylation on sulphated zirconia in mild conditions, Catal. Today 167 (2011) 56. doi: http://dx.doi.org/10.1016/j.cattod.2010.11.057

10. Dosuna-Rodriguez, I., Gaigneaux, E., Glycerol acetylation catalysed by ion exchange resins, Catal. Today 195 (2012) 14. doi: http://dx.doi.org/10.1016/j.cattod.2012.04.031

11. Jagadeeswaraiah, K., Balaraju, M., Sai Prasad, P., Linga$i a h, N$., Selective esterification of glycerol to bioadditives over heteropoly tungstate supported on Cs-containing zirconia catalysts, Appl. Catal. A: Gen. 386 (2010) 166. doi: http://dx.doi.org/10.1016/j.apcata.2010.07.046

12. Ferreira, P., Fonseca, I., Ramos, A., Vital, J., Castanheiro, $J$., Acetylation of glycerol over heteropolyacids supported on activated carbon, Catal. Commun. 12 (2011) 573. doi: http://dx.doi.org/10.1016/j.catcom.2010.11.022

13. Liao, X., Zhu, Y., Wang, S., Li, Y., Producing triacetylglycerol with glycerol by two steps: Esterification and acetylation, Fuel Proc. Technol. 90 (2009) 988. doi: http://dx.doi.org/10.1016/j.fuproc.2009.03.015

14. Guerrero-Perez, M., Rosas, J., Bedia, J., Rodriguez-Mirasol, J., Cordero, T., Recent Inventions in Glycerol Transformations and Processing, Recent Patents on Chem. Engg. 2 (2009) 11. doi: http://dx.doi.org/10.2174/2211334710902010011

15. Granados, M., Alba-Rubio, A., Vila, F., Alonso, D., Mariscal, $R$., Surface chemical promotion of Ca oxide catalysts in biodiesel production reaction by the addition of monoglycerides, diglycerides and glycerol, J. Catal. 276 (2010) 229. doi: http://dx.doi.org/10.1016/j.jcat.2010.09.016

16. Russbueldt, B., Hoelderich, W., New rare earth oxide catalysts for the transesterification of triglycerides with methanol resulting in biodiesel and pure glycerol, J. Catal. 271 (2010) 290. doi: http://dx.doi.org/10.1016/j.jcat.2010.02.005

17. Zhou, C. H., Beltramini, J., Fan, Y. X., Lu, G. Q., Chemoselective catalytic conversion of glycerol as a biorenewable source to valuable commodity chemicals, Chem. Soc. Rev. 37 (2008) 527. doi: http://dx.doi.org/10.1039/B707343G

18. Gallezot, P., Catalytic routes from renewables to fine chemicals, Catal. Today 121 (2007) 76. doi: http://dx.doi.org/10.1016/j.cattod.2006.11.019

19. Ferreira, P., Fonseca, I., Ramos, A., Vital, J., Castanheiro, $J$., Esterification of glycerol with acetic acid over dodecamolybdophosphoric acid encaged in USY zeolite, Catal. Commun. 10 (2009) 481. doi: http://dx.doi.org/10.1016/j.catcom.2008.10.015 
20. Goncalves, C., Laier, L., Jose da Silva, M., Novel Esterification of Glycerol Catalysed by Tin Chloride (II): A Recyclable and Less Corrosive Process for Production of Bio-Additives, Catal. Lett. 141 (2011) 1111 doi: http://dx.doi.org/10.1007/s10562-011-0570-x

21. Dosuna-Rodriguez, D., Adriany, C., Gaigneaux, E., Glycerol acetylation on sulphated zirconia in mild conditions, Catal. Today 167 (2011) 56-63 doi: http://dx.doi.org/10.1016/j.cattod.2010.11.057

22. Pudi, S., Mondal, T., Biswas, P., Biswas, S., Sinha, S., Conversion of Glycerol into value-added products over $\mathrm{Cu}-\mathrm{Ni}$ catalyst supported on $\gamma-\mathrm{Al}_{2} \mathrm{O}_{3}$ and activated carbon, Int. J. Chem. React. Eng. 12 (2014) 151. doi: http://dx.doi.org/10.1515/ijcre-2013-0102

23. Khayoon, M., Hameed, B., Acetylation of glycerol to biofuel additives over sulfated activated carbon catalyst, Bioresource Technol. 102 (2011) 9229-9235. doi: http://dx.doi.org/10.1016/j.biortech.2011.07.035

24. Ji, X., Chen, Y., Wang, X., Liu, W., Sulphate-functionalized multi-walled carbon nanotubes as catalysts for the esterification of glycerol with acetic acid, Kinet. Catal. 52(4) (2011) 555. doi: http://dx.doi.org/10.1134/S0023158411030104

25. Sanchez, J., Hernandez, D., Moreno, J., Mondragon, F., Fernandez, J., Alternative carbon based acid catalyst for selective esterification of glycerol to acetylglycerols, Appl. Catal. A: Gen. 405 (2011) 55 doi: http://dx.doi.org/10.1016/j.apcata.2011.07.027

26. Zhou, L., Nguyen, T., Adesina, A., The acetylation of glycerol over amberlyst-15: Kinetic and product distribution, Fuel Proc. Technol. 104 (2012) 310. doi: http://dx.doi.org/10.1016/j.fuproc.2012.06.001

27. Zhou, L., Al-Zaini, E., Adesina, A., Catalytic characteristics and parameters optimization of the glycerol acetylation over solid acid catalysts, Fuel 103 (2013) 617. doi: http://dx.doi.org/10.1016/j.fuel.2012.05.042

28. Valente, J., Cantu, M., Cortez, J., Montiel, R., Bokhimi, X., Lopez-Salinas, E., Preparation and characterization of solgel MgAl hydrotalcites with nanocapsular morphology, J. Phy. Chem. C 111 (2007) 642. doi: http://dx.doi.org/10.1021/jp065283h
29. Yang, T., Chang, T., Yeh, C., Acidities of sulfate species formed on a superacid of sulfated alumina, J. Mol. Catal. A: Chem. 115 (1997) 339. doi: http:/dx.doi.org/10.1016/S1381-1169(96)00283-X

30. Dumitriu, E., Hulea, V., Effects of channel structures and acid properties of large-pore zeolites in the liquid-phase tert-butylation of phenol, J. Catal. 218 (2003) 249. doi: http://dx.doi.org/10.1016/S0021-9517(03)00159-3

31. Khandan, N., Kazemeini, M., Aghaziarati, M., Determining an optimum catalyst for liquid-phase dehydration of methanol to dimethyl ether, Appl. Catal. A: Gen. 349 (2008) doi: http://dx.doi.org/10.1016/j.apcata.2008.07.029

32. Karim, M., Rahman, M., Miah, M., Ahmad, H., Yanagisawa, M., Ito, M., Synthesis of $\gamma$-alumina particles and surface ccharacterization, The Open Colloid Sci. J. 4 (2011) 32 . doi: http://dx.doi.org/10.2174/1876530001104010032

33. Dean, J., (1999) Lange's handbook of chemistry 15th ed., McGraw-Hill, New York

34. Mekhemer, G. A. H., Khalaf, H. A., Mansour, S. A. A., Nohman, A. K. H., Sulfated Alumina Catalysts: Consequences of Sulfate Content and Source, Monatshefte fur Chemie 136 (2005) 2007. doi: http://dx.doi.org/10.1007/s00706-005-0374-z

35. Gandarias, I., Requies, J., Arias, P., Armbruster, U., Martin, A., Liquid-phase glycerol hydrogenolysis by formic acid over $\mathrm{Ni}-\mathrm{Cu} / \mathrm{Al}_{2} \mathrm{O}_{3}$ catalysts, J. Catal. 290 (2012) 79 doi: http://dx.doi.org/10.1016/j.jcat.2012.03.004

36. Kang, M., Song, M., Kim T., Kim, K., $\gamma$-alumina supported $\mathrm{Cu}-\mathrm{Ni}$ bimetallic catalysts: Characterization and of 1,3-Butadiene, Can. J. Chem. Eng. 80 (2002) 63. doi: http://dx.doi.org/10.1002/cjce.5450800107

37. Goncalves, C., Laier, L., Cardoso, A., Silva, M., Bioadditive synthesis from $\mathrm{H}_{3} \mathrm{PW}_{12} \mathrm{O}_{40}$-catalyzed glycerol esterification with HOAc under mild reaction conditions, Fuel Proc. Technol. 102 (2012) 46. doi: http://dx.doi.org/10.1016/j.fuproc.2012.04.027 